\title{
Paramyxoviruses: Respiratory Syncytial Virus and Human Metapneumovirus
}

\author{
James E. Crowe Jr. and John V. Williams
}

\section{Human Respiratory Syncytial Virus}

\section{$1.1 \quad$ Introduction}

Human respiratory syncytial virus (RSV) and human metapneumovirus (MPV) are members of the family Paramyxoviridae of the Mononegavirales order, comprising the nonsegmented negative-strand RNA viruses. Paramyxoviridae has two subfamilies: Paramyxovirinae, which includes the parainfluenza viruses 1-4 and measles and mumps viruses, and Pneumovirinae, which includes RSV and MPV. Pneumovirinae has two genera: Pneumovirus, which includes human RSV, bovine respiratory syncytial virus, and pneumonia virus of mice, and Metapneumovirus, which includes human MPV and avian metapneumovirus, sometimes called avian pneumovirus.

\section{$1.2 \quad$ Historical Background}

RSV was isolated first in 1956 from an ill chimpanzee in a laboratory setting that had an illness similar to the common cold. A virus causing a similar cytopathic effect in cultured cells was recovered from infants with respiratory illness shortly after, and studies of human antibodies in the serum of infants and children indicated that infection was common early in life $[1,2]$. Now it is known that RSV is the most

J.E. Crowe Jr., MD

Vanderbilt in Vaccine Center,

Departments of Pediatrics, Pathology, Microbiology

and Immunology, Vanderbilt Vaccine Center,

Vanderbilt University Medical Center,

11475 Medical Research Building IV - 2213 Garland Ave.,

Nashville, TN 37232-0417, USA

e-mail: james.crowe@vanderbilt.edu

J.V. Williams, MD $(\bowtie)$

Division of Infectious Diseases,

Department of Pediatrics, Vanderbilt University Medical Center,

D-7235 MCN, Nashville, TN 37232-2581, USA

e-mail: john.williams@vanderbilt.edu common viral agent of serious pediatric respiratory tract disease worldwide. In most areas of the world, RSV is the most common cause of pneumonia and bronchiolitis in infants less than 1 year of age. RSV causes severe disease in young infants, but disease is not restricted to the early life period. The virus can cause severe lower respiratory tract illness in large numbers of elderly subjects and also in subjects who are severely immunocompromised such as hematopoietic stem cell transplant recipients [3-7].

\subsection{Epidemiologic Analysis}

\subsubsection{Mortality Data}

Mortality in infants and children caused by RSV is uncommon in developed countries with modern critical care units. Estimates of the mortality rate are about $0.3 \%$ of hospitalized children or less. Mortality has been dropping over the last several decades, and by the late 1990s the estimated number of deaths in the USA was several hundred children a year or less $[8,9]$. Large epidemiologic studies report that the US mortality in children may be only about 100 cases a year. Interestingly, while many providers think of RSV infection as principally a pediatric illness, there are over 17,000 deaths per year in the elderly, making them the highest risk population for death [9]. In less developed countries, however, infant deaths due to RSV infection may be more common.

Infants with underlying illness are at highest risk among young children for morbidity and mortality from RSV infection. Infants with chronic lung disease requiring supplemental oxygen following treatment for prematurity, due to bronchopulmonary dysplasia, are perhaps at the highest risk for prolonged, severe, or fatal illness due to RSV [10]. Infants with severe congenital pulmonary or cardiac disease have been reported to be at risk of death in 3-4\% of cases when hospitalized, although this rate is likely decreasing in the USA [11]. Both children and adults with primary immunodeficiency or medically induced immunosuppression are at 
high risk of mortality due to RSV infection. The most severely immunocompromised, and thus those at highest risk of mortality, are hematopoietic stem cell transplant patients of any age [12]. In some settings, the mortality rate of RSV infection in hematopoietic stem cell transplant patients with severe immunosuppression verges on $100 \%$ [12].

\subsubsection{Morbidity Data}

Hospitalization rates of infants for RSV disease vary with the setting, probably due to variations in exposure, genetics, socioeconomic, and other risk factors and due to the local practice style of medical providers. Many developed countries report hospitalization rates of about 1 in 100-200 infected infants during the first year of life [13, 14]. Studies of RSV disease in developed countries suggest that of those infants hospitalized, about $9 \%$ require mechanical ventilation $[15,16]$. There are certain populations at extraordinarily high risk of hospitalization with RSV, for example, Alaskan native infants younger than 1 year have been reported to have a hospitalization rate of 53-249 per 1,000 infants [16]. Low socioeconomic status is a risk factor for higher rate of hospitalization in most areas.

RSV also is one of the most common viral causes of serious lower respiratory tract illness in the elderly, especially in institutionalized subjects [17]. Exacerbations of chronic obstructive pulmonary disease (COPD) are frequently associated with RSV infection $[18,19]$. The elderly do not exhibit a remarkably diminished level of antibodies to RSV [20]. Decreased levels of $\mathrm{T}$ cell memory in the elderly and specifically in patients with (COPD) may contribute to the increased susceptibility to RSV infection in these populations [21]. Many think of influenza virus as the principal viral respiratory pathogen in this population, but in a hospitalized cohort, influenza A virus and RSV infection resulted in similar mortality, lengths of stay, and rates of use of intensive care [17]. RSV infection accounted for over $10 \%$ of hospitalizations for pneumonia.

\subsubsection{Serological Surveys}

Seroepidemiology studies suggest that virtually all children are infected in the first 2 years of life, and early infection is especially common in infants attending group day care. Serological methods are helpful in epidemiology and vaccine studies, but serologies are not often used for diagnosis in clinical settings. Because of the transfer of maternal RSVspecific antibodies across the placenta, and the high prevalence of early infection, it is unusual to find infants who are RSV seronegative. In older children and adults, a fourfold rise in serum antibodies is often used as evidence of RSV infection, but asymptomatic infections in which viral shedding is low in titer often are not accompanied by serum antibody rises. Serological tests in infants are even less sensitive, because young infants may not exhibit a large or durable rise in antibodies. Neutralizing antibody tests are considered the best functional marker of infection, but sensitivity is much higher in antigen binding assays using individually purified RSV F or G proteins [22].

\subsubsection{Laboratory Methods}

Isolation of the virus in cell culture provides a definitive test for diagnosis of active infection. Various methods of obtaining respiratory virus secretions for testing have been compared. Most studies suggested that aspiration or gentle flushing of nasal secretions using a solution like saline is best, though some types of nasal swab have given reasonable results. The virus is more thermolabile than most, and thus samples should be transported on wet ice to the diagnostic laboratory and processed rapidly. Prolonged times of transport to remote reference laboratories reduce the effectiveness of isolation. After inoculation onto susceptible cell culture substrates, highly trained staff can recognize cytopathology in the cell monolayers by visual inspection and conventional bright-field microscopy after about 3-7 days of incubation. Detection may be more efficient when using shell vial cultures and immunofluorescence [23]. Various cell lines have been used for RSV detection, such as HEp-2 epithelial cells, MRC-5 fibroblasts, and rhesus monkey kidney cells, but the R-Mix commercial mix of human and mink lung cells may perform better for detection of RSV [24].

Culture is expensive and requires highly trained staff and therefore is not usually available at the point of care, which is often an outpatient clinic or emergency department. Therefore, rapid diagnostic methods were developed for the detection of viral proteins or RNA in respiratory secretions. RSV antigen tests mostly rely on direct immunofluorescent assays (DFA) on exfoliated cells in secretions or enzyme immunoassay (EIA). Nucleic acid detection assays based on RT-PCR are now widely available for RSV, often in a multiplexed panel for detection of multiple respiratory virus pathogens. These tests are typically more sensitive than any of the virus isolation or protein-based detection assays discussed above. Enhanced sensitivity is especially helpful when testing adults, who often shed virus in very low titers. Positive RT-PCR tests need to be interpreted in the context of the clinical scenario, since the tests can remain positive for prolonged periods of time after infection, well beyond the period during which infectious virus can be isolated. Since children may experience symptomatic respiratory infections every few weeks during the winter, caution must be used in interpretation of positive PCR tests, especially when multiple viruses are detected simultaneously in a sample. Some instances of multiple PCR test positivity likely represent residual RNA from a previous virus infection and a second RNA type representing live virus from the active current infection.

RSV typically is propagated in monolayer cell cultures of continuous cell lines of human epithelial cell origin, such as HEp- 2 cells. Monkey kidney cells of various types are also 


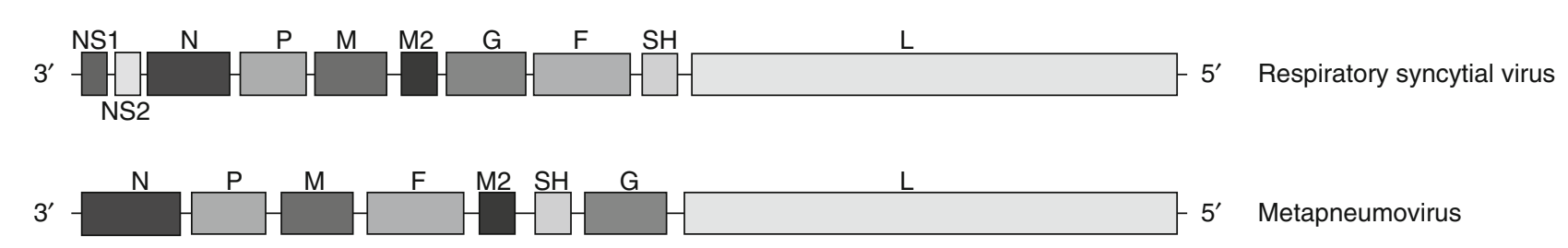

Fig. 26.1 Schematic of the genomic organization of respiratory syncytial virus and human metapneumovirus. Gene segments drawn roughly to scale

used commonly for propagation in the laboratory. In fact, the virus replicates to some extent in most cell lines of mammalian origin. In non-polarized epithelial cells, the virus often causes a typical cytopathic effect in which multinucleated giant cells form due to cell-cell fusion, termed cell syncytia. This in vitro effect is the origin of the virus name, although it is not clear that RSV causes syncytia in vivo. In polarized epithelial cells in culture, the virus assembles and buds from the apical surface of cells, mimicking to some extent the budding of virus into the lumen of the airway.

\subsection{Biological Characteristics}

The virus has a negative-sense single-stranded RNA genome with 10 genes encoding 11 proteins. Figure 26.1 compares the genomes of RSV and MPV, which are similar in many respects.

The replication proteins are common to both of the viruses, as are the matrix $(\mathrm{M})$ protein and the surface fusion $(\mathrm{F})$ and glycosylated attachment $(\mathrm{G})$ glycoproteins. The gene order differs slightly, and RSV possesses two nonstructural (NS) genes NS1 and NS2 that are not present in MPV. The functions of these genes are not fully defined, but involve interactions with the host response machinery, especially interferons. The presence of these host response-modifying genes may explain in part why RSV appears to cause severe disease more commonly than MPV. Many of the gene sequences exhibit some clear global sequence relatedness; however, the extent of the relatedness of many of the sequences of corresponding proteins is relatively low. Based on sequence homology, it is not expected that there is a significant amount of immunologic cross-reactivity in responses to the two viruses.

The RSV virion buds from airway epithelial cells, incorporating host cell membrane as the lipid bilayer that forms the envelope of the particle. Since the virus is enveloped, chemicals that disrupt lipid bilayers (detergents) inactivate the virus, leading to the strong recommendations for healthcare provider hand washing following patient contact. The genome is a single strand of RNA, which forms a helical complex with the nucleoprotein $(\mathrm{N})$. The final nucleocapsid structure likely is formed by the complete set of replication proteins, which also include the phosphoprotein $(\mathrm{P})$ and the large RNA-dependent RNA polymerase (L). It is suspected that the $\mathrm{M}$ protein helps the particle to form by bridging the nucleocapsid and the lipid envelope with its incorporated surface proteins. The surface of the particle incorporates three integral membrane surface glycoproteins, the highly glycosylated RSV G protein suspected to be the attachment protein, the fusion protein $\mathrm{F}$, and the small hydrophobic protein $(\mathrm{SH})$. RSV F (a Type I integral membrane protein) and RSV G (a Type II integral membrane protein) form oligomers on the surface of the particles, which appear like small spikes with globular heads when seen in electron microscopic (EM) images by negative stain. The morphology of particles in EM images or in fluorescent microscopy images labeled by conjugated antibodies suggests that the virion particles are filamentous. However, spherical particles, filaments, and more pleomorphic forms have been observed; therefore, it is uncertain what the morphology of infectious particles in vivo during natural infection is.

The F protein is critical for entry into cells, by breaching the barrier of the cell lipid bilayer. It is thought that binding of virion particles to susceptible cells at physiologic $\mathrm{pH}$ triggers a conformational change of the $\mathrm{F}$ protein from a metastable pre-fusion state [25] to an altered post-fusion conformation $[26,27]$ in which the hydrophobic fusion peptide in the protein is exposed and extended to insert into the host cell membrane. This membrane insertion event accomplishes a fusion of the viral and host membranes, allowing delivery of the nucleocapsid to the cytoplasm where viral replication occurs. This event is termed "fusion from without" when the particle enters a cell. An alternative fusion event ("fusion from within") occurs when newly expressed F protein on the surface of infected cells causes fusion of an infected cell to an adjacent cell in culture causing "syncytia." It is not certain whether this latter form of fusion (cell-cell fusion) occurs during natural infection and contributes to pathogenesis or if the formation of syncytia is a tissue culture phenomenon only.

\subsection{Descriptive Epidemiology}

Although there are many animal forms of RSV, there is no known animal reservoir of human RSV; close contact with infected humans is the only source of RSV infection. 


\subsubsection{Incidence and Prevalence Data}

Early prospective studies showed that approximately half of infants in the USA are infected during their first year of life; most were infected after two winter epidemics [28]. About a quarter of infants exhibit signs and symptoms of lower respiratory tract disease (wheezing and/or pneumonia) during a primary RSV infection [14, 28-31]. RSV is the most common virus associated with hospitalization for respiratory illness and in fact is one of the most common of all causes of infant hospitalization. For example, RSV caused 13 hospitalizations per 1,000 US children younger than 1 year in one large study [32]. During winter RSV epidemics, over $75 \%$ of the children hospitalized for acute lower respiratory tract infection are infected with RSV [33, 34]. The rate of very severe disease in hospitalized infants is high, with about $2-5 \%$ of hospitalized infants requiring mechanical ventilation for respiratory failure [35].

\subsubsection{Risk of Infection and Reinfection}

Although primary infection of infants is probably most efficient, RSV can infect subjects of any age [28, 36, 37]. Some adult infections are asymptomatic, and most are limited symptoms related to infection of the upper respiratory tract, such as the common cold [28, 36, 38]. Since otherwise healthy adults all possess measurable RSV serum antibodies and RSV-specific T cells, it is clear that prior exposure and induction of immune responses may not prevent infection. However, disease severity is usually reduced after one or several infections early in life, thus immune effectors such as serum neutralizing antibodies do prevent severe disease during reinfections. Unlike influenza virus, RSV does not exhibit a progressive antigenic drift. Although RSV antigenic diversity is observed in field strains, diversity of the antigenic proteins is not required for RSV to cause reinfection [39-41]. Most experts believe that serum neutralizing antibodies protect against severe lower respiratory tract disease but do not result in sterilizing immunity against infection at the respiratory mucosa. Thus, healthy adults show signs and symptoms of the common cold in about half of cases of natural or experimental infections, even though they have experienced numerous previous RSV infections [39].

There is a single serotype of RSV, but two antigenic subgroups of RSV, with about $25 \%$ antigenic relatedness, have been defined using immune sera; the subgroups are designated A and B. Antigenic dimorphism for RSV had been noted in an early study [42] and subsequently was delineated using MAbs, which identified extensive differences in the $\mathrm{G}$ protein and less extensive differences in $\mathrm{F}$ and other proteins [43]. The two subgroups exhibit a three- to fourfold reciprocal difference in neutralization by polyclonal convalescent serum. Analysis of glycoprotein-specific responses in experimental rodent models or human infants by enzymelinked immunosorbent assay (ELISA) with purified $\mathrm{F}$ and $\mathrm{G}$ glycoproteins showed that the $\mathrm{F}$ proteins are $50 \%$ related antigenically and the $\mathrm{G}$ proteins are 1-7 \% related [44]. Consistent with this level of antigenic relatedness, $F$ protein expressed by a vector immunization was equally protective in small animals against challenge with the homologous or heterologous subgroup virus, whereas the $G$ protein was 13-fold less effective against the heterologous subgroup virus [45]. Thus, the F protein is responsible for most of the observed cross-subgroup neutralization and protection. In some communities a pattern of infection with viruses of alternating subgroups has been described, but this is not a universal phenomenon. RSV subgroup B virus is more difficult to isolate and propagate in culture, so subgroup B viruses are less commonly associated with severe disease in some studies. However, clearly viruses of both subgroups can cause severe disease leading to hospitalization [46-50].

\subsubsection{Risk of Serious Lower Respiratory Infection (LRI) During Infancy}

Infants exhibit the highest risk of severe lower respiratory tract disease. This elevated risk is explained by a myriad of physiologic, immunologic, and other factors. First, the highest point of resistance in the airways is the bronchioles, and the resistance of airways is inversely proportional to the airway radius to the fourth power (resistance $\sim 1 /$ radius $^{4}$, from Poiseuille's law). The bronchioles of infants are narrow, and inflammation and secretion in the bronchioles leads to turbulent airflow, and further reduction of the airway lumen size. These physical factors lead to the clinical signs of wheezing (a sign of outflow obstruction) and air retention. Increased respiratory rate can compensate to some extent for respiratory compromise, but prolonged tachypnea can lead to fatigue and eventual respiratory failure. Also, during primary infection infants do not possess active immunity to infection, which allow this efficient virus to replicate in the airway to titers as high as $10^{7}$ infectious particles per $\mathrm{mL}$ of secretion. Mothers pass RSV antibodies to infants across the placenta during the third trimester, but premature infants do not obtain maternal antibodies prior to 32 weeks' gestation. Also, the airways of premature infants are smaller than those of term infants. Another factor leading to respiratory difficulty is dehydration. Obstruction of the nasal passages with thick secretions can impede the feeding of infants, who are obligate nose breathers.

\subsubsection{Role of RSV Infections in Adults}

RSV also is an important cause of serious infection in elderly adults; in fact RSV appears to cause substantially more fatalities in elderly adults than in children $[17,51]$. As above, a large study of the US population showed that RSV was associated with approximately 17,000 all-cause deaths per year among persons of all ages in the USA [9], with most of those deaths in the elderly. 


\subsubsection{Role of RSV in Infections with Underlying Cardiopulmonary and Other Medical Diseases}

Virtually any serious medical or genetic condition is associated with some increased risk of severe diseases [32]. Certain particular categories of subjects are at highest risk for severe RSV disease, including infants with congenital heart or chronic lung disease, immunodeficient subjects of any age and the elderly $[9,10,17,33,52-57]$. These latter subjects are thought to have reduced competency of RSV-specific T cells. Prematurity increases risk to a small extent, but more importantly chronic lung diseases are important factors $[10$, $33,56,58-62]$. Infants who are born prematurely and then suffer persistent chronic lung disease, especially those needing oxygen supplementation, are at very high risk of hospitalization with RSV. Children with cystic fibrosis are at high risk of severe disease [63, 64]. In children younger than 2 years with cystic fibrosis, the consequence of RSV infection may be prolonged respiratory morbidity [65]. Children with congenital heart disease also are at increased risk $[33,56,58$, $62,66,67]$.

\subsubsection{Role of RSV Infections in Patients with Immunodeficiency}

RSV is a common cause of severe respiratory disease in immunocompromised patients, including lower respiratory disease [68]. Mortality rates in some populations of immunocompromised patients verges on $50 \%$ [7, 69]. Infants with congenital severe combined immunodeficiency are at special risk $[57,70]$, but any acquired immunosuppressive condition such as cancer or transplantation puts patients at risk, especially when $\mathrm{T}$ cell function is compromised [68, 71, 72]. RSV infection can cause severe lung disease in recipients of lung transplants, sometimes with a long-term outcome of obliterative bronchiolitis [73-75]. Children with HIV infection shed RSV for extended periods, but disease is not especially severe in HIV-infected children prior to onset of AIDS [76-78]. Interestingly, although most immunocompromised subjects appear to be at risk because of $\mathrm{T}$ cell problems, infants with phagocytic cell defects including those with interferon- $\gamma$ receptor deficiency or chronic granulomatous disease also are at risk of severe RSV disease.

\subsubsection{Role of RSV in Nosocomial Infection}

Transmission of RSV in the hospital setting can lead to serious disease, especially in critical care units with neonates or other high-risk infants [79-86]. Nosocomial outbreaks in inpatient transplantation facilities are sometimes severe and unit outbreaks can be difficult to terminate because transplant patients can shed RSV for many months [57, 58, 69, $84,87,88]$. Theoretically, transmission in inpatient healthcare settings should be preventable through strict compliance with infection control practices, especially hand washing and contact precautions, which are universally recommended for RSV patients. A high level of compliance with precautions is difficult to achieve in busy care settings but is needed to prevent transmission by healthcare providers. The use of the prophylactic monoclonal antibody palivizumab has been studied to interrupt an outbreak in a neonatal intensive care unit setting [89], but currently palivizumab use is not recommended for this purpose.

\subsubsection{Role of RSV in Otitis Media}

Bacterial otitis media is a common complication of RSV upper respiratory tract infection. In fact, RSV infection is probably the most common precipitating factor associated with otitis media. RSV antigens and nucleic acids have been reported in middle ear fluids [90, 91]. The disease is predominantly due, however, to Eustachian tube dysfunction, resulting in bacterial stasis in the middle ear and subsequent otitis media.

\subsubsection{Epidemic Behavior}

RSV regularly occurs in annual epidemics. The US National Respiratory and Enteric Virus Surveillance System (NREVSS) considers that the RSV season starts when the first of two consecutive weeks during which the mean percentage of specimens testing positive for RSV antigen is $\geq 10 \%$. The RSV season is considered to have ended in a community when the mean percentage of positive specimens is $\leq 10 \%$ in reference laboratories for two consecutive weeks.

\subsubsection{Geographic Distribution}

RSV infection occurs in infants and adults worldwide, in yearly epidemics. The virus has been isolated in every area of the world in which surveillance studies have been conducted. The principal season varies depending on the climate and region, but infection is ubiquitous. Virtually all children in the world are infected within the first few years of life.

\subsubsection{Temporal Distribution}

Epidemics occur in the winter and early spring in the USA. Onset of the annual epidemic varies by region of the country and by year but typically begins in the USA in October or November and lasts through late spring. Within a region, the timing of RSV season changes slightly each year. Florida often has the earliest onset of RSV epidemic and the longest lasting season in the USA. Near the equator, infections may be more common during rainy season.

\subsubsection{Occurrence in Different Settings}

During community outbreaks of RSV, the venues with the highest level of young infants and children exhibit the highest rates of transmission of virus, especially large families and day-care settings with large numbers of children per 
room. Hospital infection control practices must be used to prevent RSV spread, using measures including careful hand hygiene, contact precautions for patient isolation, gowns and gloves [92, 93], and, when direct coughing occurs, facemasks and goggles [94, 95]. RSV rapid diagnostic testing can be used in hospital infection control practice to identify RSV-infected patients during the admission process [96, 97]. $\mathrm{RSV}$ is shed for prolonged periods. It has been reported that 92-100\% of hospitalized children are still shedding infectious virus after 7 days [98, 99].

\subsubsection{Environmental Risk Factors}

Exposure to tobacco smoke and poor nutrition increase the incidence of disease [100-102]. Low socioeconomic status increases the risk of severe disease for uncertain reasons. Lower income populations exhibit a five- to tenfold increased risk of hospitalization in many studies [14, 32, 103].

\subsubsection{Other Factors}

Breast-feeding may confer some protective benefit against RSV disease, but the extent of the benefit of breast-feeding has been controversial. The results of epidemiologic studies on benefit have been conflicting, although recent studies suggest that breast-feeding may have a strong protective effect only in girls [104]. The sex of the infant modulates the severity of RSV infection for additional reasons that are not fully understood. Even though the same high proportion of both male and female infants become infected, males have a higher incidence of RSV lower respiratory tract disease than girls [30, 32, 105-108]. Ethnic and genetic factors appear to play a role. Alaska and other Native American children are at increased risk of severe respiratory disease during RSV infection [109].

\subsection{Mechanisms and Routes of Transmission}

Direct contact with secretions from an infected human, usually by fomites (contaminated objects, including hands), allows transmission of virus. In some cases, infected subjects may inoculate contacts at short distance by coughing via large-particle droplets. However, the virus is not spread efficiently by small-particle aerosols [110, 111]. The nasal and conjunctival mucus membranes are probably the most common portals of entry [112]. RSV is one of the most infectious viruses spread by contact, and transmission is very efficient even among subjects who possess partial immunity due to prior infection. Spread among family members and day-care contacts is especially common. The infectious doses for humans are probably only a few infectious particles per $\mathrm{mL}$ of respiratory secretions, but infants routinely shed at least a millionfold higher concentration of virus during the peak of illness. The incubation period is not known definitely but is about 3-6 days and likely varies according to the intensity of exposure and the amount of virus in the inoculum. The period of viral shedding is many days; infants can shed infectious virus for weeks $[98,99]$. RSV can survive on hard surfaces for greater than $24 \mathrm{~h}$.

\subsection{Pathogenesis and Immunity}

Infection occurs by inoculation of the nasal or conjunctival mucosa, often by self-inoculation with infected secretions from a close contact. Adult volunteers were infected experimentally if virus was inoculated onto the conjunctival sac or into the nose, but not following introduction into the mouth [112]. The incubation period from time of inoculation to onset of illness for RSV is likely about 4-5 days [113]. Virus replication initiates in the nasopharynx and rapidly can reach concentrations of over a million particles per $\mathrm{mL}$ in the upper airway in children. Adults, who are partially immune, typically shed much lower amounts of virus. Virus spreads quickly to the lower respiratory tract, often causing symptoms within days of onset of upper respiratory symptoms. Virus may spread from cell to cell, but also it is likely that small aspirations of upper respiratory secretions with virus inoculate the lower tract.

Higher titers of virus in respiratory secretions usually are associated with increased severity of disease, in prospective studies of natural infection [114] or of clinical vaccine trials [115]. RSV infection is an acute infection and virus shedding usually resolves within days to weeks. RT-PCR tests for virus nucleic acid may remain positive for prolonged periods. Some animal studies suggest that a negligible amount of infectious virus may persist in airways far after apparent resolution of shedding, as evidenced by the recovery of low amounts of infectious virus during immunosuppression several months after infection [116].

The virus infects respiratory epithelial cells in the lung and airway. It is not clear whether RSV also replicates productively in macrophages and dendritic cells in the airway or not. RSV protein antigens have been detected in circulating mononuclear cells [117], and viral genomic RNA and mRNA have been detected by RT-PCR in blood cells [118], but this probably represents cells from the airway recirculating, as infectious virus in the blood (viremia) is not detected. RSV replicates in the cells at the luminal surface of the respiratory epithelium and virus both enters and is shed from the apical surface of infected epithelial cells [119, 120]. Studies of polarized, differentiated respiratory epithelial cells in vitro show that RSV infection preferentially infects ciliated cells at the luminal face [121], but it is not clear if infection is restricted to such cells in humans. Histopathology studies of infected humans are very limited, but show RSV antigens in 
the superficial cells of the airway in a patchy distribution, with antigen-positive cells and debris in the airway lumen.

Pathology caused by RSV infection during infant bronchiolitis includes necrosis and proliferation of the bronchiolar epithelium and destruction of ciliated epithelial cells $[120,122]$. There is an influx of a large variety of immune cell types including neutrophils, lymphocytes, and macrophages. The respiratory tissues become edematous. Mucous secretion, sloughing of dead cell debris, and the influx of apparent inflammatory cells obstruct the lumen of the narrow bronchioles and alveoli. The small diameter of infant bronchioles is easily obstructed in the presence of dead cells and edema of the airway tissues [123]. Virus-infected cells can be identified in the epithelium of the bronchi, bronchioles, and alveoli [120]. It is surprising, given the extent of disease, that RSV antigen staining is usually patchy or focal, and even in some cases of fatal RSV bronchiolitis, antigen is present only in small amounts $[119,120]$. The number of cases that have been collected is limited, however, and there is virtually no histopathology from milder cases.

RSV upper respiratory infection is complicated frequently by otitis media caused by bacteria. It is unusual to observe frank bacterial pneumonia or sepsis as a complication of RSV infection, in contrast to some other respiratory viruses like influenza. Although some clinicians may empirically use antibiotics during infant pneumonia, there is no evidence that antibiotic therapy alters the course of RSV bronchiolitis or pneumonia. Antimicrobial therapy should not be used in most cases of RSV bronchiolitis or pneumonia because of the lack of benefit and risk of selection of antibiotic-resistant colonizing organisms. Nevertheless, there is some suggestion that bacterial-viral interactions may affect the overall rate of disease in the population. It is interesting that annual RSV and influenza virus epidemics correlate directly with the time of peak incidence of invasive pneumococcal disease in many population studies [124]. A double-blind, randomized, placebo-controlled trial of pneumococcal conjugate vaccine showed a vaccine-attributable reduction in rates of childhood viral pneumonia requiring hospitalization, caused by any of seven respiratory viruses, including RSV [125].

The immune mechanisms responsible for resolution of infection and protection against reinfection by RSV are not fully defined.

Antibodies. Most experts agree that high levels of serum neutralizing antibodies are associated with relative protection against severe lower respiratory tract disease in otherwise healthy subjects. This idea is supported strongly by the observation that prophylaxis of high-risk infants with a neutralizing monoclonal antibody prevents about half of hospitalizations in that group of patients. Many population studies suggest that infants born with high levels of transplacental RSV-neutralizing maternal antibodies develop milder illness or illness at an older age than infants with low maternal antibody levels [15]. Most infants and children in whom maternal antibodies have declined to a low level make their own serum and secretory antibodies to both the F and G surface glycoproteins in response to RSV infection [126]. Antibody responses in neonates are particularly low in quality and magnitude due to immunologic immaturity and the suppressive effect of passively acquired maternal antibodies [126, 127]. Antibody-mediated immune suppression by passive antibodies primarily affects humoral rather than cellmediated immunity [128, 129]. High levels of serum antibodies do not appear to provide solid immunity against disease in the upper respiratory tract. Mucosal secretory $\operatorname{IgA}$ appears to contribute to local protection against reinfection in the airway, although potent protective IgA responses are likely relatively short lived. In human infants, the decrease in virus shedding in nasal secretions was associated with the appearance of RSV-specific IgA antibodies [130].

$T$ Cells. T cells clearly play a major role in resolution of active infection. RSV-specific T cells with cytolytic activity, thought to be CD8+ T cells, have been detected in peripheral blood mononuclear cells from infants with RSV disease [131]. Immunodeficient children, especially those with $\mathrm{T}$ cell defects, often fail to clear RSV infection and can shed virus for many months [57]. Adults with leukemia or hematopoietic stem cell transplant also have a very high incidence of prolonged RSV infection leading to severe disease and sometimes death.

\subsection{Patterns of Host Response}

\subsubsection{Symptoms}

RSV infection usually causes upper respiratory tract symptoms during primary infection in otherwise healthy term infants; asymptomatic primary infection is not common. There is often profuse rhinorrhea, and the upper tract disease is very often complicated by otitis media. Symptoms of lower respiratory tract involvement occur in about a third of primary cases [28]. The principal diagnoses are bronchiolitis (manifested by tachypnea and wheezing) and pneumonia. These entities are probably not discrete processes but more likely represent a continuum of disease involving increasing tissue distribution. The typical illness starts with nasal congestion, followed in a few days by cough. The infection is sometimes associated with fever, which is usually low grade. After several days of upper tract symptoms, infants may wheeze. Many infants suffer mild wheezing that resolves, but some cases progress with tachypnea, diffuse inspiratory crackles, and expiratory wheezes. Most children recover in 1-2 weeks with supportive care and observation. If expiratory obstruction becomes severe, however, hyper-expansion of the chest occurs due to air retention, and the compliant nature of the infant chest wall leads to intercostal and 
subcostal retractions during tachypnea. With prolonged tachypnea, fatigue may occur with poor oxygenation and $\mathrm{CO}_{2}$ retention (measured by pulse oximeter or arterial blood gas measurement), markers of respiratory failure. Intubation and mechanical ventilation is used in this setting to manage the respiratory failure.

Infection during the first day or weeks of life may just be characterized by temperature instability or fever, irritability, and lethargy even in the absence of overt respiratory signs or symptoms. In very young infants, especially those born prematurely, apneic spells may occur in response to RSV infection. Apnea may be the first reported evidence of infection in some cases, and apneic spells may recur during the acute infection. These events thankfully are usually self-limited and rarely cause neurologic damage. Apneic events are an indication for hospitalization and careful medical supervision with respiratory monitoring. Because of the association with apnea, some have considered whether RSV is associated with sudden infant death syndrome (SIDS). Although RSV has been detected in the lung tissues of some cases of SIDS, there is no statistically significant association between RSV and SIDS. The reported cases likely reflect a temporal association caused by the high prevalence of RSV in this age group, the prolonged pattern of shedding, and the simultaneous peak incidence of both RSV infection and SIDS in winter months [132].

It is not clear whether infection with RSV causes prolonged abnormal pulmonary function during childhood or whether children with underlying predisposition to lower respiratory tract disease of all causes manifest their susceptibility first to RSV because of the young age of RSV infection. Certainly measureable pulmonary function abnormalities are common after RSV lower respiratory tract disease, and these findings may persist for a decade or more [133]. Recurrent wheezing is common during subsequent viral infections after severe RSV bronchiolitis or pneumonia, with an incidence of 10-50\% [134]. A large case-control study of 200 children hospitalized for bronchiolitis or pneumonia in which RSV was the most common cause found that 7 years later there was a strong predisposition in these subjects toward decreased pulmonary function, recurrent cough, wheezing, and bronchitis [135]. Seminal prospective studies by Martinez et al. involved measurement of pulmonary function in infants at birth and then found a strong correlation between prior lower pulmonary function and the development of wheezing during RSV infection [136]. This correlation persisted in children during the first 3 years of life [136]. Even some individuals who do not typically exhibit recurrent wheezing have postexercise or pharmacologically induced bronchial reactivity [137], which may be responsive in part to bronchodilators [134].

Symptomatic upper respiratory tract RSV infections manifested by common cold symptoms are common in otherwise healthy adults, especially in those with frequent exposure to small children [80]. In the elderly, particularly those with underlying medical diseases, severe pneumonia may occur, leading to hospitalization or even death.

\subsubsection{Diagnosis}

Astute clinicians can often make a presumptive diagnosis of infection based on the clinical signs of wheezing or pneumonia in an infant during a local epidemic. Laboratory testing of nasal or lower airway secretions by antigen test (ELISA) or nucleic acid detection (by RT-PCR) provides rapid diagnosis of the presence of virus in many cases. The gold standard for diagnosis is isolation of the virus in cell culture, but this test is typically only available in referral laboratories because of the need for extensive equipment and a high level of technical expertise.

\subsection{Control and Prevention}

\subsubsection{Treatment \\ Medical Treatment}

Primary treatment is supportive care, which includes oral or intravenous hydration; monitoring of respiratory status, especially of oxygen saturation during tachypnea; use of supplemental oxygen; removal of secretions from the upper airway; and, in the case of respiratory failure, intubation and mechanical ventilation. Advances in support care in pediatric critical care units have caused a major decrease in morbidity and mortality from RSV in the developed world. Infants hospitalized for RSV disease should be monitored for apnea. Investigators have studied nitric oxide [138, 139] mixtures of helium and oxygen [140, 141] and surfactant treatment [142] in clinical experimental studies in the support of infants with severe RSV disease. Nitric oxide treatment does not appear to mediate a bronchodilator effect during RSV infection [139].

\section{Antivirals}

Therapy of RSV disease by any antiviral agent is challenging because it is a rapid acute infection, and by the time the onset of disease is recognized, it may be too late to alter the course of disease by reducing viral load. The guanosine (ribonucleic acid) analog ribavirin is a nucleoside inhibitor that inhibits viral RNA synthesis and viral mRNA capping. The drug has in vitro antiviral activity against RSV, and aerosolized ribavirin therapy has been associated with a small but statistically significant increase in oxygen saturation during the acute infection in several small studies. Decreases in mechanical ventilation and duration of RSV-associated hospitalization have not been proven (reviewed in [143]). Ribavirin was approved in 1986 in the USA for treatment of RSV infection [144]. Clinically, the drug usually is administered as a 
small-particle aerosol using a tent, mask, or mechanical ventilator, delivered for 6-18 h daily for a period of 3-7 days. The drug now is not recommended for routine use because follow-up studies have not shown a major benefit. The drug may be considered for use in select patients with documented, potentially life-threatening RSV infection. Over a dozen other experimental small molecule inhibitors of RSV fusion to cells have been described and tested in preclinical studies for inhibition of RSV, but none have progressed in development to date. A third approach employs short interfering RNAs (siRNAs), taking advantage of an ancient host cell regulatory system. Single-stranded and double-stranded RNA molecules that exhibit RSV-specific small interfering RNAs have been developed for treatment, which cause RNA interference activity against RSV, destroying the corresponding RSV RNA. These novel compounds have shown promising results in preclinical studies [145] and have been tested in small clinical trials. Human immune globulin with a high titer of RSV antibodies and the RSV monoclonal antibody palivizumab have been tested as therapy of acute RSV disease, but they were not effective for treatment of established disease.

\section{Anti-inflammatories}

Anti-inflammatory strategies have been investigated. No benefit of corticosteroid therapy on disease severity or length of hospital stay has been demonstrated, despite studies in over a dozen randomized clinical trials of outpatients or hospitalized infants with RSV bronchiolitis. Since the drug is of no benefit on its own [146] and may prolong virus shedding, it is not recommended. In the future, a possibility might be to combine an effective antiviral treatment with an antiinflammatory agent [147].

\section{Antibiotics}

Intravenous antimicrobial therapy is not appropriate in hospitalized infants with RSV bronchiolitis or pneumonia unless there is clear evidence of secondary bacterial infection. Otitis media occurs very often in infants with RSV bronchiolitis; oral antimicrobial agents can be used for therapy of otitis media if necessary.

\section{Bronchodilators}

It is intuitive to think of using beta-adrenergic agents, commonly used for the treatment of asthma, to treat the wheezing associated with RSV infection. These agents are not usually recommended for routine care of first-time wheezing associated with RSV bronchiolitis. Short-term improvements in oxygenation and clinical scores can be achieved by these therapies, but it has not been established that their use results in improvements in duration or severity of illness or disease outcomes. Studies in this area have been conflicting, but systematic reviews of randomized clinical trials of nebulized beta-agonist therapy for treatment of bronchiolitis suggest that they offer little benefit [148, 149]. Alpha-adrenergic receptor stimulation results may decrease interstitial and mucosal edema [150], and use of nebulized epinephrine (with combined alpha- and beta-adrenergic activity) has been studied with conflicting results [151, 152]. Alphaagonist stimulation of the sympathetic nervous system is expected to reduce capillary leakage by constricting precapillary arterioles, reducing hydrostatic pressure and consequently bronchial mucosal edema [150]. Racemic epinephrine treatment relieves some respiratory distress but does not affect length of stay [153]. The usefulness of such agents in the management of RSV bronchiolitis is not clear.

\subsubsection{Prevention and Immunoprophylaxis}

The most effective mode of prevention is to avoid contact with infected subjects. In the hospital setting, careful adherence to infection control practices is important for the protection of high-risk patients from RSV infection. Careful hand washing may reduce transmission in family and daycare settings. Pharmacologic intervention is indicated to prevent hospitalization for the highest risk infants, however. Passive RSV immunoprophylaxis with antibodies has proven a costly but relatively effective intervention. Parenteral infusion of RSV-neutralizing antibodies into experimental animals was shown early on to confer substantial resistance in the respiratory tract to a subsequent RSV virus challenge [154]. Significant reductions in RSV-associated hospitalizations and disease severity in high-risk human infants were first accomplished with prophylactic administration of human immunoglobulin with high RSV-neutralizing activity given by the intravenous route (RSV-IVIG; FDA licensed in 1996) [155, 156]. Monthly intravenous infusions during the RSV season reduced the frequency of pediatric hospitalization and duration of stay by approximately $55 \%$ and decreased the number of days spent in intensive care by $97 \%$. The use of RSV-IVIG was superseded by the use of a monoclonal antibody (MAb) that was developed subsequently that could be given by intramuscular route, and production of the former has been discontinued. Several MAbs were developed for immunoprophylaxis against RSV. The most successful of these was based on murine MAb 1129 [157], which is specific to the F protein and efficiently neutralizes viruses of both RSV subgroups A and B. This MAb was humanized by recombinant methods by transferring its variable regions onto a human $\operatorname{IgG} 1$ backbone, resulting in a recombinant antibody now named palivizumab [158]. This $\mathrm{MAb}$ is $50-100$-fold more effective for in vitro neutralization on a per weight basis than was RSV-IVIG, and thus the total amount of immunoglobulin administered could be reduced to an amount that could be given IM. Palivizumab (trade name Synagis) was licensed in 1998 for RSV prophylaxis of high-risk infants, following studies demonstrating its 
safety and efficacy [159-162]. Palivizumab is administered monthly through the RSV season and has been widely used in high-risk patients with prematurity, chronic lung disease, and hemodynamically significant heart disease [163]. More potent derivatives of this recombinant antibody have now been developed [164]; however, the lead candidate from these affinity maturation efforts exhibited increased side effects in a large efficacy study.

\subsubsection{Vaccines}

Prevention of severe disease probably will best be accomplished by development and use of an effective vaccine. Vaccine development for RSV has proven exceptionally difficult, however. First, young infants are a difficult population to immunize. Obstacles to immunization at this early age include immunologic immaturity and immunosuppression by maternal antibodies, as already noted [165]. Also, severe adverse events occurred in early RSV vaccine trials. A formalin-inactivated RSV vaccine candidate (FI-RSV) was developed and evaluated in infants and children in the 1960s $[166,167]$. This vaccine suspension was made by mixing concentrated, inactivated virus with alum adjuvant and was delivered by the intramuscular (IM) route. This inoculation did not protect against infection or disease, but rather during subsequent natural infection vaccinees experienced more frequent and severe disease. Most FI-RSV vaccinees (80 \%) required hospitalization during subsequent natural infection, compared to $5 \%$ in the control group. Autopsies of two fatalities showed evidence of RSV replication and pulmonary inflammation [167]. This event put a chilling effect on RSV vaccine development efforts. Therefore, RSV protein vaccines have been problematic for use in infants given their possible potential for disease enhancement, together with the poor immunogenicity in this population.

However, an RSV protein vaccine might be useful in boosting immunity in RSV-experienced older children and adults who are at increased risk of severe RSV disease due to underlying disease or advanced age. Protein vaccines for RSV have been evaluated clinically for use in such RSVexperienced individuals, in whom they appear to be safe. One experimental subunit vaccine consisted of purified $\mathrm{F}$ protein (PFP) isolated from RSV-infected cell culture. This purified protein vaccine candidate was evaluated in adults, in older children with and without underlying medical diseases, and in the elderly [168]. The PFP vaccine candidate was well tolerated and moderately immunogenic in these settings. A large multicenter study in children $1-12$ years of age with cystic fibrosis did not provide evidence of significant protection against RSV infection [169]. PFP also has been evaluated for maternal immunization in the third trimester of pregnancy. In the single study to date, the increase in antibody titers was only minimal [170]. Maternal immunization studies are being pursued currently with newer non-replicating vaccine candidates such as emulsion vaccines [171] and nanoparticle protein preparations [172, 173].

Live-attenuated vaccines represent an attractive strategy for preventing RSV, since live infection induces a balanced immune response that is not associated with enhanced disease on subsequent natural infection. Many live-attenuated RSV vaccine candidates have been developed over several decades. It has proven difficult to identify a candidate that is satisfactorily attenuated while remaining satisfactorily immunogenic in the youngest infants. Clinical trials of a safe, live-attenuated RSV vaccine for intranasal administration have shown restriction of viral replication in infants following administration of a second dose and have been encouraging [174], and additional attenuated vaccine candidates are being developed [175].

\subsection{Unresolved Problems}

Despite over 50 years of research on RSV, many challenges and questions remain. There are many unanswered fundamental questions about the biology of the organism and the pathogenesis of disease. Why does reinfection occur throughout life? What are the definitive mechanisms of immunity in humans? Is there a genetic basis for susceptibility to severe disease? Does severe RSV disease cause asthma? What drives the seasonality of RSV?

The mortality in infants has been greatly reduced in the USA through advances in critical care, but little RSV-specific intervention is available. Currently, there is little to offer for therapy except for supportive care. Prophylaxis of high-risk infant with a MAb prevents some hospitalizations but is expensive and is not always effective. There are no licensed vaccines. Given the disaster of early FI-RSV trials, it is not clear that a non-replicating vaccine can be proven safe enough in preclinical models to absolutely assure that enhanced disease will not occur. On the other hand, the explosion of new technologies for generation of recombinant RSV strains, the determination of pre- and post-fusion antigen structures, and new tools for the detailed study of the molecular and genetic basis of human immune responses suggest that much progress will be made in the RSV research field in the coming years.

\section{Human Metapneumovirus}

\section{$2.1 \quad$ Introduction}

Human metapneumovirus (HMPV, MPV) is a paramyxovirus isolated in 2001 from Dutch children with acute respiratory infection (ARI). Epidemiologic studies have since confirmed that MPV is a leading cause of upper and lower 
respiratory infection in children and adults worldwide. MPV causes many hospitalizations annually in young children and presumably deaths in developing nations. Children with comorbid conditions including prematurity, immune compromise, and chronic cardiopulmonary disease are at higher risk for severe disease. However, the majority of MPVassociated hospitalizations occur in otherwise healthy infants and children. Conversely, while MPV is associated with severe lower respiratory infection in adults at rates similar to those of influenza virus and RSV, almost all of the MPV infections in this population are in patients with comorbidities. MPV causes predictable annual outbreaks with late winter-early spring predominance in temperate regions. Substantial progress has been made in defining the biology, pathogenesis, and immunology of the virus. Small animal and nonhuman primate models of MPV have been developed and used to elucidate mechanisms of immunopathogenesis and test candidate vaccines. A variety of vaccine approaches against MPV are under study, including recombinant subunit, vectored, and live-attenuated vaccines. Human and murine monoclonal antibodies have been generated that exhibit potent in vivo efficacy in rodent models. A subset of integrins with a binding site for a natural ligand that contains an Arg-Gly-Glu (RGD) motif (RGD-binding integrins) has been identified as receptors that mediate MPV attachment and entry via an RGD motif in the MPV fusion protein. Remarkable scientific progress has been made during the decade since the discovery of MPV.

\subsection{Historical Background}

MPV was discovered by investigators in the Netherlands who cultivated specimens from children with respiratory infection on a variety of cell types [176]. A hitherto unknown virus produced cytopathic effects (CPE) in tertiary monkey kidney cells, but could not be identified by antibody staining or RT-PCR for common viruses. Electron microscopy of infected cells revealed pleomorphic enveloped particles with surface projections suggesting protein spikes, while biochemical experiments showed that the virus contained a lipid envelope and did not hemagglutinate avian or mammalian red blood cells. Elegant randomly primed RT-PCR experiments yielded multiple fragments of genome, which sequence analysis identified as related to avian metapneumovirus (AMPV).

AMPV (formerly turkey rhinotracheitis virus), identified in 1979, is an important global pathogen of poultry including turkeys and chickens [177]. There are four serotypes of AMPV (A-D), and MPV is most closely related genetically to AMPV-C [178]. Phylogenetic analysis shows that MPV likely diverged from AMPV-C 200 years ago and thus MPV is of zoonotic origin [179, 180]. However, MPV exhibits extremely restricted or no replication during experimental infection of chickens or turkeys and thus is a true human pathogen [176]. Human poultry workers exhibit serological evidence of asymptomatic infection with AMPV, providing evidence for the feasibility of an original trans-species transmission event [181].

While recently identified, MPV is not truly a new virus. Studies using archived sera collected in the 1950s revealed a $100 \%$ seroprevalence in humans greater than 5 years old [176]. Nasal washes collected prospectively during the 1970s from children with ARI had detectable MPV RNA upon retrospective testing by RT-PCR 25 years later [182]. The specialized cell culture requirements, slow growth, and limited CPE of MPV likely prevented the earlier discovery of this common respiratory pathogen.

\subsection{Methods for Epidemiologic Analysis}

\subsubsection{Sources of Mortality Data}

Limited mortality data are available and consist of sporadic case reports, case series, or the identification of fatal cases of MPV infection in research studies. MPV is not a reportable infection and there is no specific ICD-9 diagnostic code. Thus, an accurate estimate of the mortality associated with MPV is not feasible. However, lower respiratory infections are a leading cause of death in children worldwide, primarily in developing nations. MPV is a common cause of severe lower respiratory infection and thus likely accounts for a substantial number of deaths globally.

\subsubsection{Sources of Morbidity Data}

A substantial body of literature has accumulated in the last decade describing the epidemiology, disease burden, and clinical features of MPV. Many groups have used standard techniques to provide some estimate of the burden of MPV in diverse populations. Most reports have been crosssectional studies of selected populations, usually based on convenience samples of patients with acute respiratory illness. These studies are thus limited by potential selection bias, narrow time periods, and incomplete demographic or clinical data and often lack controls. Nonetheless, the broad application of these studies to sizable global populations has illuminated the frequency of MPV infection. Many of these studies have focused on special populations, such as patients with asthma, immune compromise, or chronic obstructive pulmonary disease (COPD), and thus offer valuable information about MPV among these persons.

A number of prospective, well-designed studies in adults and children have been published and offer the best estimates of the population-based incidence of MPV infection. Some of these used preexisting prospective data and samples collected prior to the discovery of MPV for retrospective 
analysis. Classical methods including active day care and clinic surveillance, as well as newer approaches such as home surveillance with parent-collected swabs, have been used. These studies have been built upon the foundations of seminal longitudinal studies conducted to investigate other viruses including influenza, parainfluenza viruses, and RSV. Taken together, these reports provide a broad survey of MPV epidemiology across diverse geographic environments, socioeconomic populations, and high-risk groups.

\subsubsection{Serological Surveys}

Seroprevalence studies using diverse methods have been performed in different populations. Most have used enzymelinked immunosorbent assay (ELISA) techniques against whole virus or purified proteins to detect IgM or IgG. A few have used immunofluorescent detection of MPV-specific antibodies or measured serum virus-neutralizing antibodies. These data have mainly been useful in determining the ubiquity of infection with MPV. Some studies have measured acute and convalescent sera to diagnose MPV infection, while others have attempted to establish a serum neutralizing titer that correlates with susceptibility to infection. Inherent limitations of serological surveys include the potential for cross-reactive antibodies and the lack of standardized reagents for MPV.

\subsubsection{Laboratory Methods}

Most studies have used RT-PCR to detect MPV due to the difficulty in cultivating the virus. The original isolation of MPV in tertiary monkey kidney cells was possible because the investigator had access to a monkey kidney cell source that was free of the endogenous simian foamy virus (A.D.M.E. Osterhaus, personal communication). Primary monkey kidney cells commercially available in the USA all contain SFV, and even the addition of anti-SFV antisera cannot prevent the growth of this endogenous virus prior to the slow emergence of MPV. Further, the fusion protein of MPV requires cleavage by exogenous trypsin for robust in vitro growth. Trypsin is added by most clinical virology laboratories only to cultures of Madin-Darby canine kidney (MDCK) cells for the isolation of influenza virus; however, MDCK cells are very poorly permissive for MPV even in the presence of trypsin. Finally, primary isolation of MPV often requires one or more passages prior to visible $\mathrm{CPE}$ and few laboratories routinely follow this procedure. Unlike RSV, MPV is not particularly labile to freeze-thaw cycles [183] and thus can be retrospectively isolated from PCR-positive specimens. Fluorescent antibody staining of patient specimens or shell vial cultures can facilitate more rapid identification [184-187].

Thus, molecular diagnostic techniques have been used for virtually all studies of MPV epidemiology. A number of sensitive and specific real-time RT-PCR assays have been described [188-195]. Many early assays were based on limited sequence data and subsequently were found to be suboptimal for detecting multiple diverse strains [195]. Both individual and multiplexed RT-PCR assays offer more sensitive detection of MPV than culture; however, multiplex assays sometimes balance decreased sensitivity for a single agent with the convenience of detecting multiple viruses simultaneously [196]. Another limitation of molecular detection for all viruses is the ability to detect low levels of viral nucleic acid in the absence of infectious virus. It has become common to detect more than one virus in a single specimen, and the interpretation of these data is far from clear. Community respiratory viral infections are frequent in childhood, and the likelihood of detecting viral genome prior to the onset of illness or for prolonged periods after illness resolution complicates the assignment of causation to one of several co-detected viruses.

\subsection{Biological Characteristics}

MPV is an enveloped pleomorphic virus ranging in size from 150 to $600 \mathrm{~nm}$, containing a single-stranded negative-sense RNA genome [178]. Complete genomic sequences of numerous MPV strains have been published [178, 180, 197]. The genome comprises eight separate open reading frames encoding nine distinct proteins (Fig. 26.1). MPV genes are analogous to those of RSV (though NS1 and NS2 are absent in MPV), but the organization of genes differs. AMPV and MPV have been taxonomically classified in the separate Metapneumovirus genus based on the gene order. Phylogenetic analysis of MPV genes consistently identifies four genetic clades, two major groups designated A and B, each with two minor groups designated A1, A2, B1, and B2 [180, 198-203]. One group has suggested further sublineages based on partial F sequence diversity [204], but there is no evidence that this further genetic distinction is of any antigenic or immunologic importance.

The two major surface proteins are the fusion $(\mathrm{F})$ and attachment $(\mathrm{G})$, with a third integral membrane short hydrophobic $(\mathrm{SH})$ protein. $\mathrm{F}$ is the target of neutralizing antibodies in animal models, F-only vaccines induce protection in animals, and F-specific monoclonal antibodies provide passive protection [205-213]. In contrast, G-specific antibodies do not neutralize virus and G-only vaccines induce neither neutralizing antibodies nor protection [206, 209, 214]. Thus, it appears that MPV is unique among human paramyxoviruses in that the attachment protein does not contribute to protective antibodies. Further, the $\mathrm{G}$ protein exhibits a high degree of genetic variability between subgroups, with as low as $29 \%$ amino acid identity between the major A and B subgroups and a minimum $60 \%$ identity within subgroups [202, 215-218]. The selective pressure for this diversity is unclear. 
In contrast to $\mathrm{G}$, the $\mathrm{F}$ protein is conserved, with a minimum $94 \%$ amino acid identity between A and B subgroups and a minimum $98 \%$ identity within subgroups [179, 202, 203]. Presumably there are functional constraints on the diversity of F, since the mutation rate of MPV is high, similar to other RNA viruses. The major question regarding the diversity between major or minor subgroups is whether it contributes to antigenic variation or escape in human populations.

Cross-neutralization against heterologous virus from the $A$ and $B$ lineages was tested using experimental infection of ferrets [202]. This study found relative neutralization of homologous to heterologous virus ranging from 12 to 96-fold difference, thus providing some evidence for antigenic serotypes. However, subsequent experiments using hamsters, African green monkeys, chimpanzees, and rhesus macaques found that the A and B groups were 64-99 \% related antigenically [219]. Infected animals developed neutralizing antibodies that were highly effective against heterologous virus, and previously infected primates were protected against challenge with heterologous virus. Cynomolgus macaques infected with A or B subgroup viruses or with candidate vaccines exhibited only a 6-16-fold difference in neutralizing titer against homologous and heterologous viruses [220, 221]. Taken together, these data show that while MPV $\mathrm{F}$ exhibits some antigenic diversity, the virus does not have truly distinct serotypes. The potential implications for human epidemiology are discussed further below.

\subsection{Descriptive Epidemiology}

\subsubsection{Incidence and Prevalence Data}

Numerous studies document the fact that MPV infection is ubiquitous and that reinfection is common. Serosurveys testing large sample collections in Canada, China, Croatia, Germany, Israel, Japan, the Netherlands, Taiwan, Thailand, the USA, and Uruguay show that $95-100 \%$ of children have antibodies against MPV by the age of 5 years [222-231]. In many of these studies, 50-75\% of children are seropositive by age 2 years, suggesting that most acquire primary MPV infection early. Most identify a decrease in serum MPV antibody titer from birth to 6-12 months, presumably due to the expected decline of maternally derived antibodies. Studies in Japan and India that compared MPV and RSV titers in the same cohort found that after the expected nadir during early infancy, RSV titers began increasing at an earlier age than MPV [232, 233]. This finding is interesting in light of epidemiologic data suggesting that primary MPV infection peaks between 6 and 12 months of life compared with the peak of RSV at 2-3 months (discussed below). Longitudinal studies in adults and children have documented reinfection by a fourfold rise in serum antibody titer [222, 230, 231, 234-237].

\subsubsection{Risk of Infection and Reinfection}

The serological data show that MPV infection is nearly ubiquitous during the first years of life. Further, reinfection occurs throughout life. In children, primary MPV infection is associated commonly with lower respiratory illness, while reinfection is associated with upper tract disease [182, 238].

\subsubsection{Risk of Serious Lower Respiratory Infection (LRI) During Infancy}

Most epidemiologic studies of MPV in children show that the virus is the second leading cause of lower respiratory infection after RSV. The prevalence of MPV in studies of children with LRI is 5-25\%. A 25-year prospective study of otherwise healthy children $<5$ years old detected MPV in $12 \%$ of children with LRI; several children experienced recurrent infection [182]. A 2-years multicenter study of inpatient and outpatient Japanese children with ARI identified MPV in 57/637 (8.9\%) [239]. A 5-years observational study of otherwise healthy Korean children $<5$ years old found MPV in 24/515 (4.7\%), similar to the rates for influenza and parainfluenza virus type 3 (PIV-3) [240]. A very large observational study in Queensland, Australia, tested specimens obtained from patients of all ages with LRI from 2001 to 2004; MPV was detected in 707/10,025 (7.1 \%). Ninety-two percent of patients with MPV were $<5$ years old, and MPV was the second most common virus after RSV in these children [241]. A South African group tested specimens from children hospitalized with ARI who were subjects in a prospective pneumococcal vaccine trial; MPV was present in $126 / 1,409(8.9 \%)$ and was the most common virus after RSV. The estimated incidence of MPV-associated hospitalization in HIV-negative children was 29/1,000; a number of children had repeat infections [242]. A prospective study of hospitalized children in Hong Kong over a 13-month period found MPV in 32/587 (5.5\%); the estimated incidence of MPV-associated hospitalization was 4.4 per 1,000 children $<6$ years old [243]. A Chinese group conducted a prospective 2-years study of children hospitalized with ARI and identified MPV in 227/878 (25.9\%), with most <6 years old [244]. A large, population-based, prospective surveillance study conducted in three US cities over 6 years found that the incidence of hospitalization for MPV in children $<5$ years old was 1 per 1,000 , lower than the rate of RSV-associated hospitalization in the same cohort $(3 / 1,000)$ but similar to the rates for influenza $(0.9 / 1,000)$ and PIV-3 $(0.5 / 1,000)$ [245].

\subsubsection{Role of MPV Infections in Adults}

Respiratory disease is among the leading causes for hospitalization of adults in the USA, and "influenza and pneumonia" ranks among the top 10 causes of deaths annually. Although the data are limited, MPV appears to be associated with a substantial burden of ARI in adults, primarily those with comorbidities. A prospective study in Rochester, NY, 
enrolled four cohorts during four winters: healthy adults $>65$, high-risk adults $>65$ with comorbidities, healthy adults 19-40 years old, and adults hospitalized for acute cardiopulmonary illness [246, 247]. Overall, MPV infection was detected in $8.5 \%$ of ARI in the cohort. The rate of MPV infection was highest in young adults at $13 \%$, though many of these were asymptomatic and detected only serologically. Of note, this group had a mean age of 33, was predominantly female, and had daily exposure to children. Of the hospitalized patients, the incidence of MPV annually ranged from 4.4 to $13.2 \%$. More than $85 \%$ of the hospitalized MPVinfected subjects had underlying conditions, chiefly cardiopulmonary disease or diabetes mellitus. There were six deaths in this study, all with comorbidities; one had concomitant bacteremia with Streptococcus pneumoniae. Interestingly, the incidence of MPV infection was similar to the annual average infection rate for RSV (5.5\%) and influenza A $(2.4 \%)$ in these cohorts during the same study period.

A prospective, population-based study in Nashville, TN, recruited adults hospitalized for ARI at several county hospitals over three winters [248]. Of 508 subjects, 23 (4.5\%) had MPV, 33 (6.5 \%) influenza, and 31 (6.1\%) RSV. Notably, MPV-infected subjects were significantly older than influenza-infected subjects (mean 76 vs. 60 years) and had higher rates of chronic cardiopulmonary disease (78\% vs. $52 \%$ ). The overall population-based rates of hospitalization for the three viruses were similar, at 1/1,000 for MPV, 1.5/1,000 RSV, and 1.2/1,000 for influenza. However, for subjects $\geq 65$ years, hospitalization rates were much higher for MPV and RSV at 2.2/1,000 for MPV and 2.5/1,000 for RSV compared to $1.2 / 1,000$ for influenza, likely reflecting the use of influenza vaccine for older adults. A prospective study of community-acquired pneumonia in Canada found MPV in $4 \%$ of hospitalized cases during an 18-month period, all with underlying conditions [249]. A Dutch group detected MPV in $2 \%$ of bronchoalveolar lavage specimens from intensive care unit patients. All were $>50$ years old with comorbid conditions and $83 \%$ died [250]. Similarly, a retrospective study in North Ireland found MPV in only $0.8 \%$ of residual respiratory specimens from adults, but $33 \%$ of these died [251]. Together, these data show that MPV is an important cause of acute respiratory disease in adults, primarily older adults or those with underlying comorbid conditions.

\subsubsection{Role of MPV Infections in Patients with Asthma}

MPV is associated with acute asthma exacerbations [252254]. MPV was detected in 10 of 132 hospitalized Finnish children with acute wheezing [255]. Similarly, MPV was isolated from $7 \%$ of adults hospitalized for acute asthma exacerbation, only one of whom tested positive 3 months later [256]. Premature infants who developed MPV bronchiolitis within the first year of life had decreased lung function at 1 year of age [257]. A prospective, case-control study of children with MPV bronchiolitis during infancy compared to infants with acute gastroenteritis found that MPV infection early in life was significantly associated with a later diagnosis of asthma and recurrent wheezing at 5 years of age [258].

\subsubsection{Role of MPV in Infections with Underlying Cardiopulmonary Disease}

MPV causes severe disease in children with comorbid conditions such as cardiac and pulmonary disease or prematurity [259-263]. A prospective 1-year study of hospitalized children found that $34 \%$ of patients with MPV had a history of prematurity, chronic lung disease, complex congenital heart disease, or immunodeficiency [264]. Vicente et al. detected MPV by RT-PCR in $6 \%$ of adults $>64$ years old with acute exacerbations of COPD; none had other pathogens identified by culture or PCR [265]. A Canadian study found that $4 \%$ of hospitalized adults with communityacquired pneumonia or COPD exacerbations tested positive for MPV, all with comorbid conditions; one also had influenza A and S. pneumoniae [266]. RSV was present in $9 \%$ and influenza A in $6 \%$ of the cohort. MPV was detected in $12 \%$ of adults hospitalized for COPD exacerbation during one winter in Connecticut, none with other viruses codetected; RSV was present in $8 \%$ and influenza A in $4 \%$ of the entire cohort [267].

\subsubsection{Role of MPV Infections in Patients with Immunodeficiency}

Severe and fatal MPV disease can occur among immunocompromised individuals, including solid organ and stem cell transplant recipients, HIV-infected persons, and chemotherapy patients [268-275]. MPV is associated with morbidity and mortality in adults with hematologic malignancies and stem cell transplant; [270, 276] MPV was detected in bronchoalveolar lavage specimens from 5/163 (3\%) episodes of acute respiratory infection in stem cell transplant recipients, and four died [270]. HIV-positive South African children with MPV were significantly more likely to receive a diagnosis of pneumonia and experience longer hospitalization, lower mean oxygen saturation, and bacteremia; further, HIV-positive children were fivefold more likely to be infected with MPV than HIV-negative children [242].

\subsubsection{Role of MPV in Nosocomial Infection}

MPV has been implicated in several hospital and institutional outbreaks leading to mortality [277, 278]. Kim and colleagues [279] report the transmission of MPV to pediatric hematology-oncology patients during a nosocomial outbreak. The incubation period was between 7 and 9 days. Standard, but not droplet, precautions were used. In laboratory studies, infectious virus persists on metal and nonporous surfaces for up to $8 \mathrm{~h}$ [183]. Due to the significant morbidity and mortality of MPV in high-risk children, isolation precautions are important. 


\subsubsection{Role of MPV in Different Clinical Syndromes}

MPV is associated with both upper and lower respiratory tract disease [182, 280-282]. Rhinorrhea and cough are the most frequent symptoms, while hoarseness, laryngitis, sore throat, and croup are less common [238-241, 243, 282]. A large prospective study of children with URI detected MPV in $5 \%$ of patients, similar to RSV, influenza, and PIV but less frequent than adenovirus and rhinovirus. In these children with URI associated with MPV, fever was present in $54 \%$, coryza in $82 \%$, cough in $66 \%$, pharyngitis in $44 \%$, hoarseness in $8 \%$, and conjunctivitis in $3 \%$ [280]. MPV is associated with acute otitis media and has been detected in nasal secretions and middle ear fluid [182, 280, 283-285].

Signs and symptoms of LRI with MPV include cough, wheezing, and rhonchi. A large Chinese study of children with acute respiratory infections found that wheezing was more common in children with MPV than with RSV [282]. In that study, children with MPV were diagnosed with pneumonia significantly more than children with RSV, $47 \%$ versus $31 \%(p=0.002)$. Conversely, a larger percentage of children with RSV were diagnosed with bronchiolitis compared to MPV, $62 \%$ versus $42 \%$, respectively $(p<0.001)$. Other studies also note the trend toward a higher percentage of children with MPV and pneumonia compared to RSV [182, 238, 245] although this is not always statistically significant [243].

MPV has been associated rarely with neurologic complications, including febrile seizures and altered mental status, but there is no conclusive evidence for direct neural infection. One case report describes a patient who died and had MPV isolated by RT-PCR from brain and lung tissues [286]. MPV was detected by RT-PCR in nasal specimens from 4 of 1,570 persons with encephalitis of unknown etiology [287]. Several other reports describe the detection of MPV in a respiratory specimen from patients with encephalitis [286, 288-290]. Only one case reports detection of MPV in cerebrospinal fluid [291].

\subsubsection{Epidemic Behavior}

The incidence of viral infection varies between countries and years, but MPV circulates in every year [176, 182, 239-241, 243, 282, 292-296].

\subsubsection{Geographic Distribution}

Epidemiologic studies have verified the presence of MPV worldwide.

\subsubsection{Temporal Distribution}

MPV is present during all months in temperate regions, although predominant in late winter-early spring, often following the peak of RSV (Fig. 26.2) [176, 182, 191, 239, 241, 246, 264, 280, 282, 294, 297].

In subtropical climates such as Hong Kong, a springsummer season similar to RSV occurs [243]. Biannual peaks of seasonality have been described in some European studies [298, 299]. Annual rates of MPV-associated ARI are lower than RSV and comparable to parainfluenza virus types 1-3 combined and influenza [240, 241, 243, 282, 294, 300] although MPV does on occasion surpass RSV in incidence [293].

\subsubsection{Occurrence in Different Settings}

Multiple outbreaks have been reported in nursing homes and other long-term care facilities (LTCF). MPV was the only pathogen identified in an outbreak of ARI that occurred over a 6-weeks period at a Quebec LTCF, with 6 PCR-confirmed and 96 epidemiologically linked probable cases. There were three deaths among the confirmed and nine deaths among the probable cases [278]. A California study described an outbreak of ARI in 26/148 (18\%) residents and, importantly, 13 staff of a LTCF; MPV was confirmed in 5 residents, 2 of whom were hospitalized, and no other viruses were detected in any case [301].

\subsubsection{Environmental Risk Factors}

Attendance in out-of-home day care, breast-feeding, and passive smoke exposure are not significantly associated with MPV infection [245]. MPV infection is not associated with lower socioeconomic status.

\subsubsection{Other Factors}

Viral coinfection has been suggested with MPV; dual infection with RSV and MPV increased the risk of PICU admission compared to RSV alone in one small study [302]. However, this finding was refuted by subsequent larger reports [303-305]. Other studies demonstrate no significant difference in children with coinfections, including adenovirus, bocavirus, coronavirus, influenza virus, parainfluenza viruses, or RSV [240, 241, 282, 293, 306, 307].

MPV has four distinct genetic lineages or subgroups: A1, A2, B2, and B2 [202, 203, 218]. The predominant subtype varies by year and location [241, 280, 293, 297, 308]. In Italy, over a 3-years period, all four subtypes were identified each season but the predominant subtype changed. In 20012002, A1 accounted for $59 \%$ of all strains, the following year B1 and B2 were present equally, and in 2003-2004, $72 \%$ of strains were A2 [308]. Similar variation was observed over 20 years in a US study, with multiple subgroups present in most seasons (Fig. 26.3) [280].

It is unclear whether viruses from different subgroups differ in virulence. A study in Spain reported that children with group A infection more frequently had pneumonia and higher disease severity [309], while in Canada, group B was associated with more severe disease in hospitalized patients [261]. Patients with group B strains in a French study were more likely to have abnormal chest radiographs but did not have significant differences in oxygen saturation, hospitalizations, or clinical severity scores [310]. Other studies have found no major distinctions in disease severity [239, 241, 

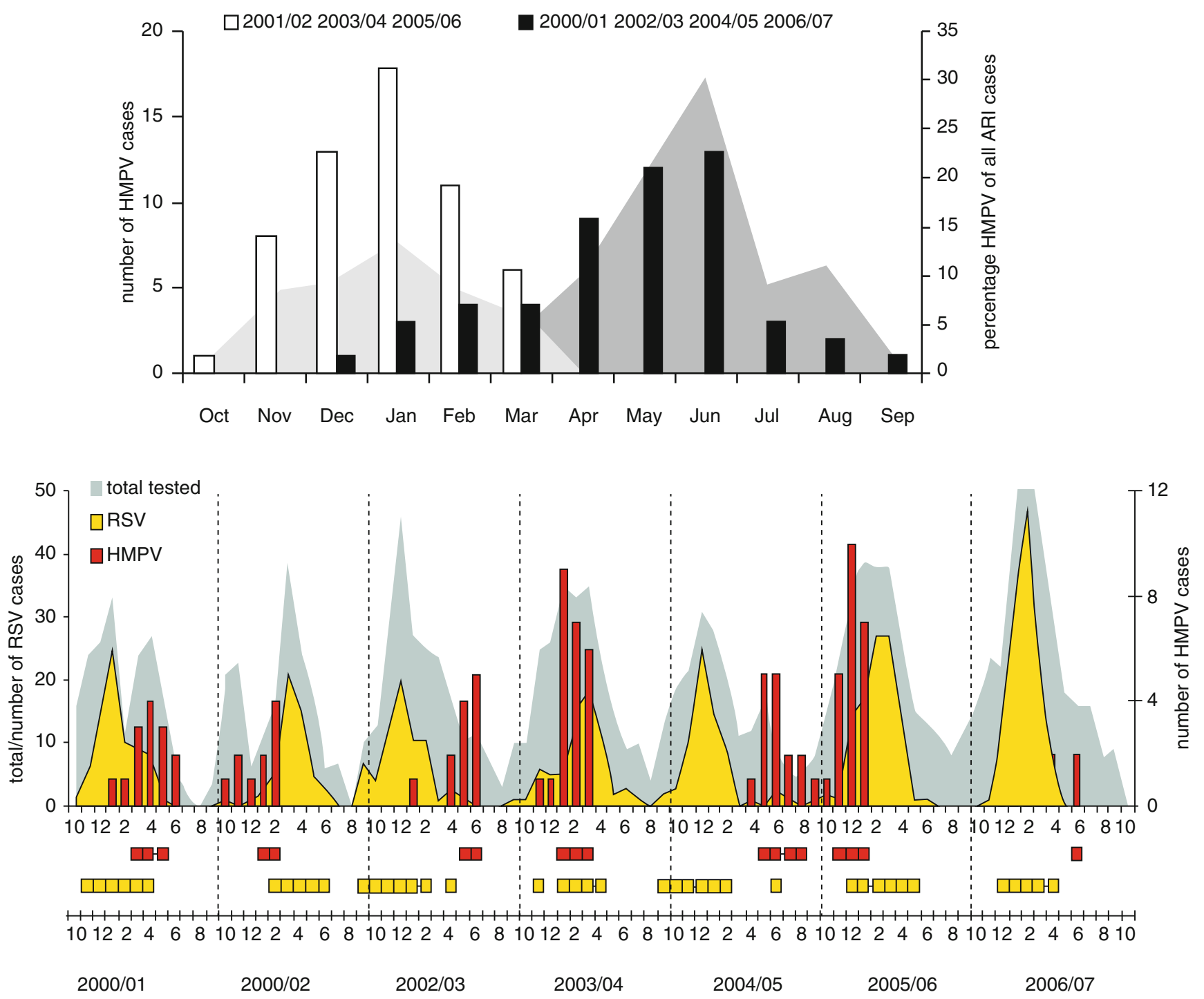

Fig. 26.2 Number of infants admitted to hospital with acute respiratory illness and the seasonality of RSV and MPV in Austria from 2000 to 2007 (top panel). The weeks of onset and end of RSV and MPV activity (bottom panel) are defined as the first of 2 consecutive weeks

where $>10 \%$ of specimens test positive by PCR and the last week of $>10 \%$ positive preceding 2 consecutive weeks of $<10 \%$ positive. Gray indicates total tested; yellow, RSV; red, HMPV (Used with permission from Aberle et al. [298])

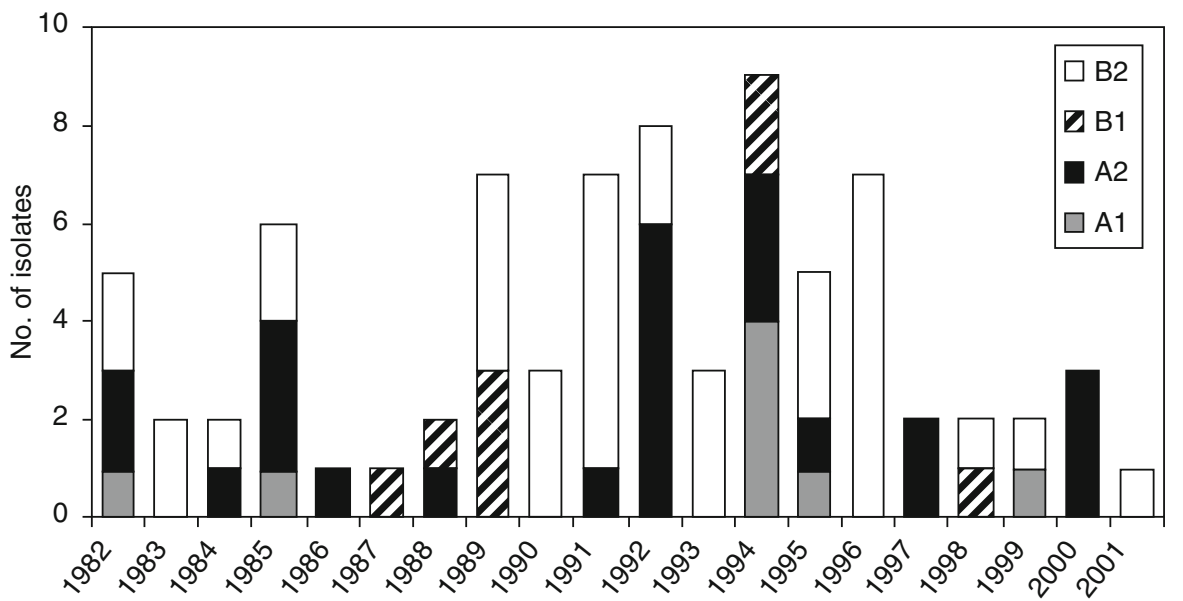

Fig.26.3 Rates, by year, of each genetic lineage of human metapneumovirus. Data are from specimens collected from children with acute respiratory infection between 1982 and 2001 in the Vanderbilt Vaccine Clinic (Used with permission from Williams et al. [280]) 
311], laboratory abnormalities [228], or symptoms [240] between subgroups. Group A viruses replicate more efficiently in animal models, suggesting some meaningful biological differences between groups [219, 220].

\subsection{Mechanisms and Routes of Transmission}

MPV is an enveloped virus and thus inactivated by soap, disinfectants, or alcohols. Spread is thought to occur by direct or close contact with contaminated secretions. Infectious virus can persist at room temperature, especially nonporous surfaces, for up to $8 \mathrm{~h}$ [183]. Contact precautions are recommended as for RSV with meticulous hand hygiene. Cohorting of patients and caregivers should be considered during outbreaks in care facilities.

\subsection{Pathogenesis and Immunity}

Human data are limited; studies in rodents and nonhuman primates reveal mild erosive and inflammatory changes in the mucosa and submucosa of the airways, with viral replication observed in ciliated epithelial cells in the respiratory tract [312-314]. Inflammatory infiltrates with a lymphocytic and monocytic predominance are present in perivascular and peribronchial areas. Sumino and colleagues [315] reviewed the lung pathology of five adults with MPV infection. Histopathology in three patients demonstrated acute, organizing lung injury with diffuse alveolar membrane formation and the presence of smudge cells. The fourth patient had no evidence of lower respiratory tract infection, and the fifth patient had nonspecific acute and chronic inflammation. A similar study in children revealed chronic inflammatory changes of the airways with intra-alveolar macrophages [316]. A major limitation of reports of human pathology is that patients had been mechanically ventilated prior to death, making it difficult to distinguish virus-induced pathology from barotrauma and nonspecific inflammation.

MPV lacks genes present in other paramyxoviruses that inhibit interferon responses; nevertheless, MPV is capable of blocking type I interferon responses by an unknown mechanism [317, 318]. MPV and other respiratory viruses induce pulmonary $\mathrm{CD} 8+\mathrm{T}$ cells that fail to secrete IFN $\gamma$ or exhibit cytotoxic degranulation in response to viral peptides; these impaired CD8 T cells resemble exhausted CD8 T cells induced by chronic infections such as HIV and hepatitis C virus [319].

Humans develop neutralizing antibodies to MPV, and passive antibodies alone can protect in animal models. However, immunity wanes over time and likely provides limited cross-protection between subgroups, since reinfections occur in children and adults [246, 248] with genetically different strains $[182,239,240,268,320]$ as well as strains from the same subgroup [280]. Early protection against reinfection following primary infection was confirmed in macaques; however, when challenged 12 weeks later, virus replication was detectable despite the presence of serum antibodies [220]. Eleven months later, antibody levels had waned still further, and all macaques challenged with heterologous virus and two of three animals reinfected with homologous virus had no evidence of protection [220]. A prospective study in humans noted that baseline MPV antibodies were lower in patients who subsequently became infected versus those who did not become infected [321]. Thus, cross-protection and duration of antibody responses are important issues for vaccine development.

\subsection{Patterns of Host Response}

\subsubsection{Symptoms}

MPV causes both upper and lower respiratory tract signs and symptoms clinically indistinguishable from disease associated with RSV and other respiratory viruses [182, 239, 300, $322,323]$. Fever is present in most cases, especially children [239-241, 243, 264, 280, 293]. Transient maculopapular rash has been described in a minority of patients [241, 243, 293], and vomiting or diarrhea are described with low frequency [182, 239, 243]. Laboratory abnormalities are uncommon, although one study identified $27 \%$ of patients with elevated ALT and AST values [293]. White blood cell count and C-reactive protein were not significantly different between RSV and MPV [238, 282].

MPV is rarely detected in asymptomatic persons [182, 191, 324-326], though in otherwise healthy young adults, MPV infection can be subclinical [246]. The duration of shedding in healthy individuals is approximately 7-14 days $[239,327]$.

\subsubsection{Diagnosis}

Detection in cell culture requires prolonged incubation and is both insensitive and often impractical. Shell vial culture offers increased sensitivity over traditional culture [184, 328]. IFA has demonstrated a sensitivity of $73 \%$ and specificity of $97 \%$ with RT-PCR as the gold standard [329]. DFA has shown similar results [330]. Commercial antibody kits for immunofluorescent detection of MPV are available. RT-PCR is most commonly used for detection of the virus in epidemiologic studies and is becoming more common in clinical laboratories [176, 320, 331, 332]. Real-time RT-PCR targeting the conserved $\mathrm{N}$ gene has high sensitivity for detection of all four subgroups [189, 195]. 


\subsection{Control and Prevention}

\subsubsection{Treatment}

The primary therapy for MPV infections is supportive care, including oral or intravenous hydration, monitoring of respiratory status and oxygen saturation, supplemental oxygen, and mechanical ventilation for frank respiratory failure. There are no licensed antivirals for MPV. Reports of pharmacologic treatment of MPV are limited to severely ill or immunocompromised patients. Ribavirin, an antiviral agent used in severe RSV infection, reduced inflammation and viral replication in mice with MPV infection [333]. Commercial intravenous immunoglobulin (IVIG), ribavirin, and NMSO3 (a sulfated sialyl lipid) effectively inhibited MPV in vitro [334, 335]. Ribavirin, with and without IVIG, has been used in immunocompromised adults [336]. Bonney and colleagues [337] reported successful treatment of an immunocompromised child with MPV using IV ribavirin and IVIG. Subsequently, oral ribavirin and inhaled ribavirin with IVIG have been used [275, 338]. However, no randomized, controlled trials have been conducted, and these data should be regarded as purely anecdotal.

\subsubsection{Immunoprophylaxis}

Human and murine monoclonal antibodies exhibit therapeutic efficacy in rodent models and thus offer potential for immunoprophylaxis [210, 211, 213].

\subsubsection{Vaccines}

A number of vaccine approaches for MPV have been investigated. The $\mathrm{F}$ protein is conserved between subgroups, immunogenic, and the only target of neutralizing antibodies; in contrast to RSV, the MPV G protein does not induce neutralizing antibodies and is not a protective antigen [206, 209, 214]. A recombinant parainfluenza virus encoding the MPV F protein demonstrated protection against MPV [339], and soluble $\mathrm{F}$ protein vaccines reduced viral titers in cotton rats and hamsters [207, 208]. Reverse genetics technology has been developed for MPV and has been used to produce recombinant strains for vaccine development [197, 340]. Viruses lacking the G, M2-1, M2-2, or SH proteins or with point mutations are attenuated and immunogenic in rodent and primate models [197, 221, 341-344].

\subsection{Unresolved Problems}

The major unresolved problems in MPV epidemiology and research involve understanding mechanisms of disease and developing therapeutic or preventive strategies. Abundant evidence shows that MPV is a significant cause of acute respiratory disease, especially in the very young, older adults, and persons with underlying conditions. As with all mucosal viruses, the short incubation period of MPV com- bined with the transient nature of mucosal $\operatorname{IgA}$ means that reinfection is possible throughout life. However, serum IgG appears to offer protection against severe lower respiratory involvement, and thus a vaccine would likely ameliorate the most severe cases. The best candidate vaccine is not yet clear. Further, MPV has as yet unidentified mechanisms to subvert host immunity. Elucidation of these pathways might help guide vaccine development and uncover novel host targets for immunomodulation.

\section{References}

1. Chanock R, Finberg L. Recovery from infants with respiratory illness of a virus related to chimpanzee coryza agent (CCA). II. Epidemiologic aspects of infection in infants and young children. Am J Hyg. 1957;66:291-300.

2. Chanock R, Roizman B, Myers R. Recovery from infants with respiratory illness of a virus related to chimpanzee coryza agent (CCA). I. Isolation, properties and characterization. Am J Hyg. 1957;66:281-90.

3. Dowell SF, Anderson LJ, Gary Jr HE, et al. Respiratory syncytial virus is an important cause of community-acquired lower respiratory infection among hospitalized adults. J Infect Dis. 1996; $174: 456-62$.

4. Martin MA, Bock MJ, Pfaller MA, Wenzel RP. Respiratory syncytial virus infections in adult bone marrow transplant recipients. Lancet. 1988;1:1396-7.

5. Hertz MI, Englund JA, Snover D, Bitterman PB, McGlave PB. Respiratory syncytial virus-induced acute lung injury in adult patients with bone marrow transplants: a clinical approach and review of the literature. Medicine. 1989;68: 269-81.

6. Fouillard L, Mouthon L, Laporte JP, et al. Severe respiratory syncytial virus pneumonia after autologous bone marrow transplantation: a report of three cases and review. Bone Marrow Transplant. 1992;9:97-100.

7. Harrington RD, Hooton TM, Hackman RC, et al. An outbreak of respiratory syncytial virus in a bone marrow transplant center. J Infect Dis. 1992;165:987-93.

8. Shay DK, Holman RC, Roosevelt GE, Clarke MJ, Anderson LJ. Bronchiolitis-associated mortality and estimates of respiratory syncytial virus-associated deaths among US children, 1979-1997. J Infect Dis. 2001;183:16-22.

9. Thompson WW, Shay DK, Weintraub E, et al. Mortality associated with influenza and respiratory syncytial virus in the United States. JAMA. 2003;289:179-86.

10. Groothuis JR, Gutierrez KM, Lauer BA. Respiratory syncytial virus infection in children with bronchopulmonary dysplasia. Pediatrics. 1988;82:199-203.

11. Fixler DE. Respiratory syncytial virus infection in children with congenital heart disease: a review. Pediatr Cardiol. 1996;17: $163-8$.

12. Whimbey E, Champlin RE, Couch RB, et al. Community respiratory virus infections among hospitalized adult bone marrow transplant recipients. Clin Infect Dis. 1996;22:778-82.

13. Fisher RG, Gruber WC, Edwards KM, et al. Twenty years of outpatient respiratory syncytial virus infection: a framework for vaccine efficacy trials. Pediatrics. 1997;99:E7.

14. Kim HW, Arrobio JO, Brandt CD, et al. Epidemiology of respiratory syncytial virus infection in Washington, D.C. I. Importance of the virus in different respiratory tract disease syndromes and temporal distribution of infection. Am J Epidemiol. 1973;98: 216-25. 
15. Glezen WP, Paredes A, Allison JE, Taber LH, Frank AL. Risk of respiratory syncytial virus infection for infants from low-income families in relationship to age, sex, ethnic group, and maternal antibody level. J Pediatr. 1981;98:708-15.

16. Karron RA, Singleton RJ, Bulkow L, et al. Severe respiratory syncytial virus disease in Alaska native children. RSV Alaska Study Group. J Infect Dis. 1999;180:41-9.

17. Falsey AR, Hennessey PA, Formica MA, Cox C, Walsh EE. Respiratory syncytial virus infection in elderly and high-risk adults. N Engl J Med. 2005;352:1749-59.

18. Falsey AR, Formica MA, Hennessey PA, Criddle MM, Sullender WM, Walsh EE. Detection of respiratory syncytial virus in adults with chronic obstructive pulmonary disease. Am J Respir Crit Care Med. 2006;173:639-43.

19. Rohde G, Wiethege A, Borg I, et al. Respiratory viruses in exacerbations of chronic obstructive pulmonary disease requiring hospitalisation: a case-control study. Thorax. 2003;58:37-42.

20. Falsey AR, Walsh EE, Looney RJ, et al. Comparison of respiratory syncytial virus humoral immunity and response to infection in young and elderly adults. J Med Virol. 1999;59: 221-6.

21. de Bree GJ, Heidema J, van Leeuwen EM, et al. Respiratory syncytial virus-specific CD8+ memory $\mathrm{T}$ cell responses in elderly persons. J Infect Dis. 2005;191:1710-8.

22. Walsh EE, Schlesinger JJ, Brandriss MW. Purification and characterization of GP90, one of the envelope glycoproteins of respiratory syncytial virus. J Gen Virol. 1984;65(Pt 4):761-7.

23. Johnston SL, Siegel CS. Evaluation of direct immunofluorescence, enzyme immunoassay, centrifugation culture, and conventional culture for the detection of respiratory syncytial virus. J Clin Microbiol. 1990;28:2394-7.

24. Barenfanger J, Drake C, Mueller T, Troutt T, O’Brien J, Guttman K. $\mathrm{R}-\mathrm{Mix}$ cells are faster, at least as sensitive and marginally more costly than conventional cell lines for the detection of respiratory viruses. J Clin Virol. 2001;22:101-10.

25. McLellan JS, Chen M, Leung S, et al. Structure of RSV fusion glycoprotein trimer bound to a prefusion-specific neutralizing antibody. Science. 2013;340:1113-7.

26. Swanson KA, Settembre EC, Shaw CA, et al. Structural basis for immunization with postfusion respiratory syncytial virus fusion $\mathrm{F}$ glycoprotein (RSV F) to elicit high neutralizing antibody titers. Proc Natl Acad Sci U S A. 2011;108:9619-24.

27. McLellan JS, Yang Y, Graham BS, Kwong PD. Structure of respiratory syncytial virus fusion glycoprotein in the postfusion conformation reveals preservation of neutralizing epitopes. J Virol. 2011;85:7788-96.

28. Glezen WP, Taber LH, Frank AL, Kasel JA. Risk of primary infection and reinfection with respiratory syncytial virus. Am J Dis Child. 1986;140:543-6.

29. Brandt CD, Kim HW, Arrobio JO, et al. Epidemiology of respiratory syncytial virus infection in Washington, D.C. 3. Composite analysis of eleven consecutive yearly epidemics. Am J Epidemiol. 1973;98:355-64.

30. Parrott RH, Kim HW, Arrobio JO, et al. Epidemiology of respiratory syncytial virus infection in Washington, D.C. II. Infection and disease with respect to age, immunologic status, race and sex. Am J Epidemiol. 1973;98:289-300.

31. Hall CB. Respiratory syncytial virus and parainfluenza virus. $\mathrm{N}$ Engl J Med. 2001;344:1917-28.

32. Iwane MK, Edwards KM, Szilagyi PG, et al. Population-based surveillance for hospitalizations associated with respiratory syncytial virus, influenza virus, and parainfluenza viruses among young children. Pediatrics. 2004;113:1758-64.

33. Boyce TG, Mellen BG, Mitchel Jr EF, Wright PF, Griffin MR. Rates of hospitalization for respiratory syncytial virus infection among children in Medicaid. J Pediatr. 2000;137: $865-70$.
34. Shay DK, Holman RC, Newman RD, Liu LL, Stout JW, Anderson LJ. Bronchiolitis-associated hospitalizations among US children, 1980-1996. JAMA. 1999;282:1440-6.

35. Leader S, Kohlhase K. Respiratory syncytial virus-coded pediatric hospitalizations, 1997 to 1999. Pediatr Infect Dis J. 2002; 21:629-32.

36. Henderson FW, Collier AM, Clyde Jr WA, Denny FW. Respiratorysyncytial-virus infections, reinfections and immunity. A prospective, longitudinal study in young children. $\mathrm{N}$ Engl $\mathrm{J}$ Med. 1979;300:530-4.

37. Hall CB, Geiman JM, Biggar R, Kotok DI, Hogan PM, Douglas Jr GR. Respiratory syncytial virus infections within families. N Engl J Med. 1976;294:414-9.

38. Hall CB, Long CE, Schnabel KC. Respiratory syncytial virus infections in previously healthy working adults. Clin Infect Dis. 2001;33:792-6.

39. Sullender WM, Mufson MA, Prince GA, Anderson LJ, Wertz GW. Antigenic and genetic diversity among the attachment proteins of group A respiratory syncytial viruses that have caused repeat infections in children. J Infect Dis. 1998;178:925-32.

40. Waris M. Pattern of respiratory syncytial virus epidemics in Finland: two-year cycles with alternating prevalence of groups A and B. J Infect Dis. 1991;163:464-9.

41. Mufson MA, Belshe RB, Orvell C, Norrby E. Subgroup characteristics of respiratory syncytial virus strains recovered from children with two consecutive infections. J Clin Microbiol. 1987;25: 1535-9.

42. Coates HV, Alling DW, Chanock RM. An antigenic analysis of respiratory syncytial virus isolates by a plaque reduction neutralization test. Am J Epidemiol. 1966;83:299-313.

43. Anderson LJ, Hierholzer JC, Tsou C, et al. Antigenic characterization of respiratory syncytial virus strains with monoclonal antibodies. J Infect Dis. 1985;151:626-33.

44. Hendry RM, Burns JC, Walsh EE, et al. Strain-specific serum antibody responses in infants undergoing primary infection with respiratory syncytial virus. J Infect Dis. 1988;157:640-7.

45. Johnson PR, Spriggs MK, Olmsted RA, Collins PL. The G glycoprotein of human respiratory syncytial viruses of subgroups A and B: extensive sequence divergence between antigenically related proteins. Proc Natl Acad Sci U S A. 1987;84:5625-9.

46. McIntosh ED, De Silva LM, Oates RK. Clinical severity of respiratory syncytial virus group A and B infection in Sydney, Australia. Pediatr Infect Dis J. 1993;12:815-9.

47. Hall CB, Walsh EE, Schnabel KC, et al. Occurrence of groups A and $\mathrm{B}$ of respiratory syncytial virus over 15 years: associated epidemiologic and clinical characteristics in hospitalized and ambulatory children. J Infect Dis. 1990;162:1283-90.

48. Walsh EE, McConnochie KM, Long CE, Hall CB. Severity of respiratory syncytial virus infection is related to virus strain. J Infect Dis. 1997;175:814-20.

49. McConnochie KM, Hall CB, Walsh EE, Roghmann KJ. Variation in severity of respiratory syncytial virus infections with subtype. J Pediatr. 1990;117:52-62.

50. Gilca R, De Serres G, Tremblay M, et al. Distribution and clinical impact of human respiratory syncytial virus genotypes in hospitalized children over 2 winter seasons. J Infect Dis. 2006;193:54-8.

51. Sethi S, Murphy TF. RSV infection-not for kids only. N Engl J Med. 2005;352:1810-2.

52. Khongphatthanayothin A, Wong PC, Samara Y, et al. Impact of respiratory syncytial virus infection on surgery for congenital heart disease: postoperative course and outcome. Crit Care Med. 1999;27:1974-81.

53. Arnold SR, Wang EE, Law BJ, et al. Variable morbidity of respiratory syncytial virus infection in patients with underlying lung disease: a review of the PICNIC RSV database. Pediatric Investigators Collaborative Network on Infections in Canada. Pediatr Infect Dis J. 1999;18:866-9. 
54. Joffe S, Escobar GJ, Black SB, Armstrong MA, Lieu TA Rehospitalization for respiratory syncytial virus among premature infants. Pediatrics. 1999;104:894-9.

55. Milner ME, de la Monte SM, Hutchins GM. Fatal respiratory syncytial virus infection in severe combined immunodeficiency syndrome. Am J Dis Child. 1985;139:1111-4.

56. MacDonald NE, Hall CB, Suffin SC, Alexson C, Harris PJ, Manning JA. Respiratory syncytial viral infection in infants with congenital heart disease. N Engl J Med. 1982;307:397-400.

57. Hall CB, Powell KR, MacDonald NE, et al. Respiratory syncytial viral infection in children with compromised immune function. N Engl J Med. 1986;315:77-81.

58. Navas L, Wang E, de Carvalho V, Robinson J. Improved outcome of respiratory syncytial virus infection in a high-risk hospitalized population of Canadian children. Pediatric Investigators Collaborative Network on Infections in Canada. J Pediatr. 1992;121:348-54.

59. Cunningham AS, Jelliffe DB, Jelliffe EF. Breast-feeding and health in the 1980s: a global epidemiologic review. J Pediatr. 1991; 118:659-66.

60. Nachman SA, Navaie-Waliser M, Qureshi MZ. Rehospitalization with respiratory syncytial virus after neonatal intensive care unit discharge: a 3-year follow-up. Pediatrics. 1997;100:E8.

61. Wang EE, Law BJ, Robinson JL, et al. PICNIC (Pediatric Investigators Collaborative Network on Infections in Canada) study of the role of age and respiratory syncytial virus neutralizing antibody on respiratory syncytial virus illness in patients with underlying heart or lung disease. Pediatrics. 1997;99:E9.

62. Resch B, Pasnocht A, Gusenleitner W, Muller W. Rehospitalisations for respiratory disease and respiratory syncytial virus infection in preterm infants of 29-36 weeks gestational age. J Infect. 2005;50:397-403.

63. Hordvik NL, Konig P, Hamory B, et al. Effects of acute viral respiratory tract infections in patients with cystic fibrosis. Pediatr Pulmonol. 1989;7:217-22.

64. Abman SH, Ogle JW, Butler-Simon N, Rumack CM, Accurso FJ. Role of respiratory syncytial virus in early hospitalizations for respiratory distress of young infants with cystic fibrosis. J Pediatr. 1988;113:826-30.

65. Hiatt PW, Grace SC, Kozinetz CA, et al. Effects of viral lower respiratory tract infection on lung function in infants with cystic fibrosis. Pediatrics. 1999;103:619-26.

66. Moler FW, Khan AS, Meliones JN, Custer JR, Palmisano J, Shope TC. Respiratory syncytial virus morbidity and mortality estimates in congenital heart disease patients: a recent experience. Crit Care Med. 1992;20:1406-13.

67. Cabalka AK. Physiologic risk factors for respiratory viral infections and immunoprophylaxis for respiratory syncytial virus in young children with congenital heart disease. Pediatr Infect Dis J. 2004;23:S41-5.

68. Couch RB, Englund JA, Whimbey E. Respiratory viral infections in immunocompetent and immunocompromised persons. Am J Med. 1997;102:2-9; discussion 25-6.

69. Champlin RE, Whimbey E. Community respiratory virus infections in bone marrow transplant recipients: the M.D. Anderson Cancer Center experience. Biol Blood Marrow Transplant. 2001;7(Suppl):8S-10.

70. Gelfand EW, McCurdy D, Rao CP, Middleton PJ. Ribavirin treatment of viral pneumonitis in severe combined immunodeficiency disease. Lancet. 1983;2:732-3.

71. Bowden RA. Respiratory virus infections after marrow transplant: the Fred Hutchinson Cancer Research Center experience. Am J Med. 1997;102:27-30; discussion 42-3.

72. Wendt $\mathrm{CH}$. Community respiratory viruses: organ transplant recipients. Am J Med. 1997;102:31-6; discussion 42-3.

73. Palmer Jr SM, Henshaw NG, Howell DN, Miller SE, Davis RD, Tapson VF. Community respiratory viral infection in adult lung transplant recipients. Chest. 1998;113:944-50.
74. Krinzman S, Basgoz N, Kradin R, et al. Respiratory syncytial virusassociated infections in adult recipients of solid organ transplants. J Heart Lung Transplant. 1998;17:202-10.

75. Kramer MR, Marshall SE, Starnes VA, Gamberg P, Amitai Z, Theodore J. Infectious complications in heart-lung transplantation. Analysis of 200 episodes. Arch Intern Med. 1993;153:2010-6.

76. Chandwani S, Borkowsky W, Krasinski K, Lawrence R, Welliver R. Respiratory syncytial virus infection in human immunodeficiency virus-infected children. J Pediatr. 1990;117:251-4.

77. Madhi SA, Venter M, Madhi A, Petersen MK, Klugman KP. Differing manifestations of respiratory syncytial virus-associated severe lower respiratory tract infections in human immunodeficiency virus type 1-infected and uninfected children. Pediatr Infect Dis J. 2001;20:164-70.

78. Madhi SA, Schoub B, Simmank K, Blackburn N, Klugman KP. Increased burden of respiratory viral associated severe lower respiratory tract infections in children infected with human immunodeficiency virus type-1. J Pediatr. 2000;137:78-84.

79. Hall CB. Nosocomial respiratory syncytial virus infections: the "Cold War" has not ended. Clin Infect Dis. 2000;31:590-6.

80. Hall CB, Douglas Jr RG, Geiman JM, Messner MK. Nosocomial respiratory syncytial virus infections. $N$ Engl $J$ Med. 1975;293:1343-6.

81. Hall CB, Geiman JM, Douglas Jr RG, Meagher MP. Control of nosocomial respiratory syncytial viral infections. Pediatrics. 1978:62:728-32.

82. Hall CB, Kopelman AE, Douglas Jr RG, Geiman JM, Meagher MP. Neonatal respiratory syncytial virus infection. N Engl J Med. 1979;300:393-6.

83. Langley JM, LeBlanc JC, Wang EE, et al. Nosocomial respiratory syncytial virus infection in Canadian pediatric hospitals: a Pediatric Investigators Collaborative Network on Infections in Canada Study. Pediatrics. 1997;100:943-6.

84. Englund JA, Anderson LJ, Rhame FS. Nosocomial transmission of respiratory syncytial virus in immunocompromised adults. J Clin Microbiol. 1991;29:115-9.

85. Thorburn K, Kerr S, Taylor N, van Saene HK. RSV outbreak in a paediatric intensive care unit. J Hosp Infect. 2004;57:194-201.

86. Halasa NB, Williams JV, Wilson GJ, Walsh WF, Schaffner W, Wright PF. Medical and economic impact of a respiratory syncytial virus outbreak in a neonatal intensive care unit. Pediatr Infect Dis J. 2005;24:1040-4.

87. Englund J, Glezen WP, Piedra PA. Maternal immunization against viral disease. Vaccine. 1998;16:1456-63.

88. Pohl C, Green M, Wald ER, Ledesma-Medina J. Respiratory syncytial virus infections in pediatric liver transplant recipients. J Infect Dis. 1992;165:166-9.

89. Abadesso C, Almeida HI, Virella D, Carreiro MH, Machado MC. Use of palivizumab to control an outbreak of syncytial respiratory virus in a neonatal intensive care unit. J Hosp Infect. 2004;58:38-41.

90. Okamoto Y, Kudo K, Ishikawa K, et al. Presence of respiratory syncytial virus genomic sequences in middle ear fluid and its relationship to expression of cytokines and cell adhesion molecules. J Infect Dis. 1993;168:1277-81.

91. Sarkkinen H, Ruuskanen O, Meurman O, Puhakka H, Virolainen E, Eskola J. Identification of respiratory virus antigens in middle ear fluids of children with acute otitis media. J Infect Dis. 1985;151:444-8.

92. Madge P, Paton JY, McColl JH, Mackie PL. Prospective controlled study of four infection-control procedures to prevent nosocomial infection with respiratory syncytial virus. Lancet. 1992;340:1079-83.

93. Leclair JM, Freeman J, Sullivan BF, Crowley CM, Goldmann DA. Prevention of nosocomial respiratory syncytial virus infections through compliance with glove and gown isolation precautions. N Engl J Med. 1987;317:329-34. 
94. Agah R, Cherry JD, Garakian AJ, Chapin M. Respiratory syncytial virus (RSV) infection rate in personnel caring for children with RSV infections. Routine isolation procedure vs routine procedure supplemented by use of masks and goggles. Am J Dis Child. 1987;141:695-7.

95. Gala CL, Hall CB, Schnabel KC, et al. The use of eye-nose goggles to control nosocomial respiratory syncytial virus infection. JAMA. 1986;256:2706-8.

96. Beekmann SE, Engler HD, Collins AS, Canosa J, Henderson DK, Freifeld A. Rapid identification of respiratory viruses: impact on isolation practices and transmission among immunocompromised pediatric patients. Infect Control Hosp Epidemiol. 1996; 17:581-6.

97. Garcia R, Raad I, Abi-Said D, et al. Nosocomial respiratory syncytial virus infections: prevention and control in bone marrow transplant patients. Infect Control Hosp Epidemiol. 1997; 18:412-6.

98. Hall CB, Douglas Jr RG, Geiman JM. Respiratory syncytial virus infections in infants: quantitation and duration of shedding. J Pediatr. 1976;89:11-5.

99. Hall CB, Douglas Jr RG, Geiman JM. Quantitative shedding patterns of respiratory syncytial virus in infants. $J$ Infect Dis. 1975;132:151-6.

100. Simoes EA. Environmental and demographic risk factors for respiratory syncytial virus lower respiratory tract disease. J Pediatr. 2003;143:S118-26.

101. Figueras-Aloy J, Carbonell-Estrany X, Quero J, Group IS. Casecontrol study of the risk factors linked to respiratory syncytial virus infection requiring hospitalization in premature infants born at a gestational age of 33-35 weeks in Spain. Pediatr Infect Dis J. 2004;23:815-20.

102. Law BJ, Langley JM, Allen U, et al. The Pediatric Investigators Collaborative Network on Infections in Canada study of predictors of hospitalization for respiratory syncytial virus infection for infants born at 33 through 35 completed weeks of gestation. Pediatr Infect Dis J. 2004;23:806-14.

103. Parrott RH, Kim HW, Brandt CD, Chanock RM. Respiratory syncytial virus in infants and children. Prev Med. 1974;3: 473-80.

104. Klein MI, Bergel E, Gibbons L, et al. Differential gender response to respiratory infections and to the protective effect of breast milk in preterm infants. Pediatrics. 2008;121:e1510-6.

105. Holberg CJ, Wright AL, Martinez FD, Ray CG, Taussig LM, Lebowitz MD. Risk factors for respiratory syncytial virusassociated lower respiratory illnesses in the first year of life. Am J Epidemiol. 1991;133:1135-51.

106. Glezen WP, Loda FA, Clyde Jr WA, et al. Epidemiologic patterns of acute lower respiratory disease of children in a pediatric group practice. J Pediatr. 1971;78:397-406.

107. Glezen P, Denny FW. Epidemiology of acute lower respiratory disease in children. N Engl J Med. 1973;288:498-505.

108. Hall CB, Douglas Jr RG. Clinically useful method for the isolation of respiratory syncytial virus. J Infect Dis. 1975;131:1-5.

109. Lowther SA, Shay DK, Holman RC, Clarke MJ, Kaufman SF, Anderson LJ. Bronchiolitis-associated hospitalizations among American Indian and Alaska Native children. Pediatr Infect Dis J. 2000;19:11-7.

110. Hall CB, Douglas Jr RG. Modes of transmission of respiratory syncytial virus. J Pediatr. 1981;99:100-3.

111. Hall CB, Douglas Jr RG, Geiman JM. Possible transmission by fomites of respiratory syncytial virus. J Infect Dis. 1980; 141:98-102.

112. Hall CB, Douglas Jr RG, Schnabel KC, Geiman JM. Infectivity of respiratory syncytial virus by various routes of inoculation. Infect Immun. 1981;33:779-83.

113. Kapikian AZ, Bell JA, Mastrota FM, Johnson KM, Huebner RJ, Chanock RM. An outbreak of febrile illness and pneumonia associated with respiratory syncytial virus infection. Am J Hyg. 1961;74:234-48.

114. DeVincenzo JP, El Saleeby CM, Bush AJ. Respiratory syncytial virus load predicts disease severity in previously healthy infants. J Infect Dis. 2005;191:1861-8.

115. Wright PF, Gruber WC, Peters M, et al. Illness severity, viral shedding, and antibody responses in infants hospitalized with bronchiolitis caused by respiratory syncytial virus. J Infect Dis. 2002; 185:1011-8.

116. Schwarze J, O'Donnell DR, Rohwedder A, Openshaw PJ. Latency and persistence of respiratory syncytial virus despite T cell immunity. Am J Respir Crit Care Med. 2004;169: $801-5$.

117. Domurat F, Roberts Jr NJ, Walsh EE, Dagan R. Respiratory syncytial virus infection of human mononuclear leukocytes in vitro and in vivo. J Infect Dis. 1985; 152:895-902.

118. O’Donnell DR, McGarvey MJ, Tully JM, Balfour-Lynn IM, Openshaw PJ. Respiratory syncytial virus RNA in cells from the peripheral blood during acute infection. J Pediatr. 1998;133: 272-4.

119. Gardner PS, McQuillin J, Court SD. Speculation on pathogenesis in death from respiratory syncytial virus infection. $\mathrm{Br}$ Med J. 1970;1:327-30.

120. Neilson KA, Yunis EJ. Demonstration of respiratory syncytial virus in an autopsy series. Pediatr Pathol. 1990;10:491-502.

121. Zhang L, Peeples ME, Boucher RC, Collins PL, Pickles RJ. Respiratory syncytial virus infection of human airway epithelial cells is polarized, specific to ciliated cells, and without obvious cytopathology. J Virol. 2002;76:5654-66.

122. Aherne W, Bird T, Court SD, Gardner PS, McQuillin J. Pathological changes in virus infections of the lower respiratory tract in children. J Clin Pathol. 1970;23:7-18.

123. Hogg JC, Williams J, Richardson JB, Macklem PT, Thurlbeck WM. Age as a factor in the distribution of lower-airway conductance and in the pathologic anatomy of obstructive lung disease. $\mathrm{N}$ Engl J Med. 1970;282:1283-7.

124. Talbot TR, Poehling KA, Hartert TV, et al. Seasonality of invasive pneumococcal disease: temporal relation to documented influenza and respiratory syncytial viral circulation. Am J Med. 2005; 118:285-91.

125. Madhi SA, Klugman KP, Vaccine Trialist G. A role for Streptococcus pneumoniae in virus-associated pneumonia. Nat Med. 2004;10:811-3.

126. Murphy BR, Alling DW, Snyder MH, et al. Effect of age and preexisting antibody on serum antibody response of infants and children to the $\mathrm{F}$ and $\mathrm{G}$ glycoproteins during respiratory syncytial virus infection. J Clin Microbiol. 1986;24:894-8.

127. Murphy BR, Olmsted RA, Collins PL, Chanock RM, Prince GA Passive transfer of respiratory syncytial virus (RSV) antiserum suppresses the immune response to the RSV fusion (F) and large (G) glycoproteins expressed by recombinant vaccinia viruses. J Virol. 1988;62:3907-10.

128. Cannon MJ. Microplaque immunoperoxidase detection of infectious respiratory syncytial virus in the lungs of infected mice. J Virol Methods. 1987;16:293-301.

129. Siegrist CA, Barrios C, Martinez X, et al. Influence of maternal antibodies on vaccine responses: inhibition of antibody but not $\mathrm{T}$ cell responses allows successful early prime-boost strategies in mice. Eur J Immunol. 1998;28:4138-48.

130. McIntosh K, Masters HB, Orr I, Chao RK, Barkin RM. The immunologic response to infection with respiratory syncytial virus in infants. J Infect Dis. 1978;138: 24-32.

131. Brandenburg AH, Kleinjan A, van Het Land B, et al. Type 1-like immune response is found in children with respiratory syncytial virus infection regardless of clinical severity. J Med Virol. 2000; 62:267-77. 
132. Cubie HA, Duncan LA, Marshall LA, Smith NM. Detection of respiratory syncytial virus nucleic acid in archival postmortem tissue from infants. Pediatr Pathol Lab Med. 1997;17:927-38.

133. Johnston ID. Effect of pneumonia in childhood on adult lung function. J Pediatr. 1999;135:33-7.

134. Castro-Rodriguez JA, Holberg CJ, Wright AL, et al. Association of radiologically ascertained pneumonia before age $3 \mathrm{yr}$ with asthmalike symptoms and pulmonary function during childhood: a prospective study. Am J Respir Crit Care Med. 1999;159: 1891-7.

135. Mok JY, Simpson H. Outcome of acute lower respiratory tract infection in infants: preliminary report of seven-year follow-up study. Br Med J. 1982;285:333-7.

136. Martinez FD, Morgan WJ, Wright AL, Holberg C, Taussig LM. Initial airway function is a risk factor for recurrent wheezing respiratory illnesses during the first three years of life. Group Health Medical Associates. Am Rev Respir Dis. 1991;143: 312-6.

137. Sims DG, Downham MA, Gardner PS, Webb JK, Weightman D. Study of 8-year-old children with a history of respiratory syncytial virus bronchiolitis in infancy. Br Med J. 1978;1:11-4.

138. Hoehn T, Krause M, Krueger M, Hentschel R. Treatment of respiratory failure with inhaled nitric oxide and high- frequency ventilation in an infant with respiratory syncytial virus pneumonia and bronchopulmonary dysplasia. Respiration. 1998;65:477-80.

139. Patel NR, Hammer J, Nichani S, Numa A, Newth CJ. Effect of inhaled nitric oxide on respiratory mechanics in ventilated infants with RSV bronchiolitis. Intensive Care Med. 1999;25:81-7.

140. Hollman G, Shen G, Zeng L, et al. Helium-oxygen improves Clinical Asthma Scores in children with acute bronchiolitis. Crit Care Med. 1998;26:1731-6.

141. Martinon-Torres F, Rodriguez-Nunez A, Martinon-Sanchez JM. Heliox therapy in infants with acute bronchiolitis. Pediatrics. 2002;109:68-73.

142. Tibby SM, Hatherill M, Wright SM, Wilson P, Postle AD, Murdoch IA. Exogenous surfactant supplementation in infants with respiratory syncytial virus bronchiolitis. Am J Respir Crit Care Med. 2000;162:1251-6.

143. Ventre K, Randolph A. Ribavirin for respiratory syncytial virus infection of the lower respiratory tract in infants and young children. Cochrane Database Syst Rev. 2004; 4:CD000181.

144. Ventre K, Randolph AG. Ribavirin for respiratory syncytial virus infection of the lower respiratory tract in infants and young children. Cochrane Database Syst Rev. 2007;1:CD000181.

145. Bitko V, Musiyenko A, Shulyayeva O, Barik S. Inhibition of respiratory viruses by nasally administered siRNA. Nat Med. 2005;11:50-5.

146. Patel H, Platt R, Lozano JM, Wang EE. Glucocorticoids for acute viral bronchiolitis in infants and young children. Cochrane Database Syst Rev. 2004;3:CD004878.

147. Blanco JC, Boukhvalova MS, Hemming P, Ottolini MG, Prince GA. Prospects of antiviral and anti-inflammatory therapy for respiratory syncytial virus infection. Expert Rev Anti Infect Ther. 2005;3:945-55.

148. Kellner JD, Ohlsson A, Gadomski AM, Wang EE. Efficacy of bronchodilator therapy in bronchiolitis. A meta-analysis. Arch Pediatr Adolesc Med. 1996;150:1166-72.

149. Kellner JD, Ohlsson A, Gadomski AM, Wang EE. Bronchodilators for bronchiolitis. Cochrane Database Syst Rev. 2000;2:CD001266.

150. Barr FE, Patel NR, Newth CJ. The pharmacologic mechanism by which inhaled epinephrine reduces airway obstruction in respiratory syncytial virus-associated bronchiolitis. J Pediatr. 2000;136: 699-700.

151. Abul-Ainine A, Luyt D. Short term effects of adrenaline in bronchiolitis: a randomised controlled trial. Arch Dis Child. 2002;86: 276-9.
152. Sanchez I, De Koster J, Powell RE, Wolstein R, Chernick V. Effect of racemic epinephrine and salbutamol on clinical score and pulmonary mechanics in infants with bronchiolitis. J Pediatr. 1993;122:145-51.

153. Langley JM, Smith MB, LeBlanc JC, Joudrey H, Ojah CR, Pianosi P. Racemic epinephrine compared to salbutamol in hospitalized young children with bronchiolitis; a randomized controlled clinical trial. BMC Pediatr. 2005;5:7.

154. Prince GA, Horswood RL, Chanock RM. Quantitative aspects of passive immunity to respiratory syncytial virus infection in infant cotton rats. J Virol. 1985;55:517-20.

155. Groothuis JR, Simoes EA, Levin MJ, et al. Prophylactic administration of respiratory syncytial virus immune globulin to high-risk infants and young children. The Respiratory Syncytial Virus Immune Globulin Study Group. N Engl J Med. 1993;329: 1524-30.

156. Simoes EA, Sondheimer HM, Top Jr FH, et al. Respiratory syncytial virus immune globulin for prophylaxis against respiratory syncytial virus disease in infants and children with congenital heart disease. The Cardiac Study Group. J Pediatr. 1998;133: 492-9.

157. Beeler JA, van Wyke Coelingh K. Neutralization epitopes of the F glycoprotein of respiratory syncytial virus: effect of mutation upon fusion function. J Virol. 1989;63:2941-50.

158. Johnson S, Oliver C, Prince GA, et al. Development of a humanized monoclonal antibody (MEDI-493) with potent in vitro and in vivo activity against respiratory syncytial virus. J Infect Dis. 1997; 176:1215-24.

159. Saez-Llorens X, Castano E, Null D, et al. Safety and pharmacokinetics of an intramuscular humanized monoclonal antibody to respiratory syncytial virus in premature infants and infants with bronchopulmonary dysplasia. The MEDI-493 Study Group. Pediatr Infect Dis J. 1998;17:787-91.

160. The IMpact-RSV Study Group. Palivizumab, a humanized respiratory syncytial virus monoclonal antibody, reduces hospitalization from respiratory syncytial virus infection in high-risk infants. Pediatrics. 1998;102:531-7.

161. Subramanian KN, Weisman LE, Rhodes T, et al. Safety, tolerance and pharmacokinetics of a humanized monoclonal antibody to respiratory syncytial virus in premature infants and infants with bronchopulmonary dysplasia. MEDI-493 Study Group. Pediatr Infect Dis J. 1998;17:110-5.

162. Feltes TF, Cabalka AK, Meissner HC, et al. Palivizumab prophylaxis reduces hospitalization due to respiratory syncytial virus in young children with hemodynamically significant congenital heart disease. J Pediatr. 2003;143:532-40.

163. Meissner HC, Long SS, American Academy of Pediatrics Committee on Infectious D, Committee on F, Newborn. Revised indications for the use of palivizumab and respiratory syncytial virus immune globulin intravenous for the prevention of respiratory syncytial virus infections. Pediatrics. 2003; 112:1447-52.

164. Wu H, Pfarr DS, Tang Y, et al. Ultra-potent antibodies against respiratory syncytial virus: effects of binding kinetics and binding valence on viral neutralization. J Mol Biol. 2005;350:126-44.

165. Crowe Jr JE, Williams JV. Immunology of viral respiratory tract infection in infancy. Paediatr Respir Rev. 2003;4:112-9.

166. Kapikian AZ, Mitchell RH, Chanock RM, Shvedoff RA, Stewart CE. An epidemiologic study of altered clinical reactivity to respiratory syncytial (RS) virus infection in children previously vaccinated with an inactivated RS virus vaccine. Am J Epidemiol. 1969;89:405-21.

167. Prince GA, Curtis SJ, Yim KC, Porter DD. Vaccine-enhanced respiratory syncytial virus disease in cotton rats following immunization with Lot 100 or a newly prepared reference vaccine. J Gen Virol. 2001;82:2881-8. 
168. Falsey AR, Walsh EE. Safety and immunogenicity of a respiratory syncytial virus subunit vaccine (PFP-2) in the institutionalized elderly. Vaccine. 1997;15:1130-2.

169. Piedra PA, Cron SG, Jewell A, et al. Immunogenicity of a new purified fusion protein vaccine to respiratory syncytial virus: a multi-center trial in children with cystic fibrosis. Vaccine. 2003;21:2448-60.

170. Munoz FM, Piedra PA, Glezen WP. Safety and immunogenicity of respiratory syncytial virus purified fusion protein-2 vaccine in pregnant women. Vaccine. 2003;21:3465-7.

171. Lindell DM, Morris SB, White MP, et al. A novel inactivated intranasal respiratory syncytial virus vaccine promotes viral clearance without Th2 associated vaccine-enhanced disease. PLoS One. 2011;6:e21823.

172. Glenn GM, Smith G, Fries L, et al. Safety and immunogenicity of a Sf9 insect cell-derived respiratory syncytial virus fusion protein nanoparticle vaccine. Vaccine. 2013;31:524-32.

173. Smith G, Raghunandan R, Wu Y, et al. Respiratory syncytial virus fusion glycoprotein expressed in insect cells form protein nanoparticles that induce protective immunity in cotton rats. PLoS One. 2012; 7:e50852.

174. Karron RA, Wright PF, Belshe RB, et al. Identification of a recombinant live attenuated respiratory syncytial virus vaccine candidate that is highly attenuated in infants. J Infect Dis. 2005;191:1093-104.

175. Wright PF, Karron RA, Madhi SA, et al. The interferon antagonist NS2 protein of respiratory syncytial virus is an important virulence determinant for humans. J Infect Dis. 2006;193:573-81.

176. van den Hoogen BG, de Jong JC, Groen J, et al. A newly discovered human pneumovirus isolated from young children with respiratory tract disease. Nat Med. 2001;7:719-24.

177. Njenga MK, Lwamba HM, Seal BS. Metapneumoviruses in birds and humans. Virus Res. 2003;91:163-9.

178. van den Hoogen BG, Bestebroer TM, Osterhaus AD, Fouchier RA. Analysis of the genomic sequence of a human metapneumovirus. Virology. 2002;295:119-32.

179. de Graaf M, Osterhaus AD, Fouchier RA, Holmes EC. Evolutionary dynamics of human and avian metapneumoviruses. J Gen Virol. 2008;89:2933-42.

180. Piyaratna R, Tollefson SJ, Williams JV. Genomic analysis of four human metapneumovirus prototypes. Virus Res. 2011;160:200-5.

181. Kayali G, Ortiz EJ, Chorazy ML, et al. Serologic evidence of avian metapneumovirus infection among adults occupationally exposed to turkeys. Vector Borne Zoonotic Dis. 2011;11:1453-8.

182. Williams JV, Harris PA, Tollefson SJ, et al. Human metapneumovirus and lower respiratory tract disease in otherwise healthy infants and children. N Engl J Med. 2004;350:443-50.

183. Tollefson SJ, Cox RG, Williams JV. Studies of culture conditions and environmental stability of human metapneumovirus. Virus Res. 2010;151:54-9.

184. Landry ML, Ferguson D, Cohen S, Peret TC, Erdman DD. Detection of human metapneumovirus in clinical samples by immunofluorescence staining of shell vial centrifugation cultures prepared from three different cell lines. J Clin Microbiol. 2005;43:1950-2.

185. Gerna G, Sarasini A, Percivalle E, Genini E, Campanini G, Grazia Revello M. Simultaneous detection and typing of human metapneumovirus strains in nasopharyngeal secretions and cell cultures by monoclonal antibodies. J Clin Virol. 2006;35:113-6.

186. Jun KR, Woo YD, Sung H, Kim MN. Detection of human metapneumovirus by direct antigen test and shell vial cultures using immunofluorescent antibody staining. J Virol Methods. 2008;152:109-11.

187. Vinh DC, Newby D, Charest H, McDonald J. Evaluation of a commercial direct fluorescent-antibody assay for human metapneumovirus in respiratory specimens. J Clin Microbiol. 2008;46:1840-1.

188. Mackay IM, Jacob KC, Woolhouse D, et al. Molecular assays for detection of human metapneumovirus. $\mathrm{J}$ Clin Microbiol. 2003;41:100-5.

189. Maertzdorf J, Wang CK, Brown JB, et al. Real-time reverse transcriptase PCR assay for detection of human metapneumoviruses from all known genetic lineages. J Clin Microbiol. 2004;42:981-6.

190. Kuypers J, Wright N, Corey L, Morrow R. Detection and quantification of human metapneumovirus in pediatric specimens by realtime RT-PCR. J Clin Virol. 2005;33:299-305.

191. Falsey AR, Criddle MC, Walsh EE. Detection of respiratory syncytial virus and human metapneumovirus by reverse transcription polymerase chain reaction in adults with and without respiratory illness. J Clin Virol. 2006;35:46-50.

192. Carr MJ, Waters A, Fenwick F, Toms GL, Hall WW, O'Kelly E. Molecular epidemiology of human metapneumovirus in Ireland. J Med Virol. 2008;80:510-6.

193. Ginocchio CC, Manji R, Lotlikar M, Zhang F. Clinical evaluation of NucliSENS magnetic extraction and NucliSENS analytespecific reagents for real-time detection of human metapneumovirus in pediatric respiratory specimens. J Clin Microbiol. 2008;46:1274-80.

194. Hopkins MJ, Redmond C, Shaw JM, et al. Detection and characterisation of human metapneumovirus from children with acute respiratory symptoms in north-west England, UK. J Clin Virol. 2008;42:273-9.

195. Klemenc J, Asad Ali S, Johnson M, et al. Real-time reverse transcriptase PCR assay for improved detection of human metapneumovirus. J Clin Virol. 2012;54:371-5.

196. Ali SA, Gern JE, Hartert TV, et al. Real-world comparison of two molecular methods for detection of respiratory viruses. Virol J. 2011;8:332.

197. Biacchesi S, Skiadopoulos MH, Tran KC, Murphy BR, Collins PL, Buchholz UJ. Recovery of human metapneumovirus from cDNA: optimization of growth in vitro and expression of additional genes. Virology. 2004;321:247-59.

198. Bastien N, Normand S, Taylor T, et al. Sequence analysis of the N, $\mathrm{P}, \mathrm{M}$ and $\mathrm{F}$ genes of Canadian human metapneumovirus strains. Virus Res. 2003;93:51-62.

199. Biacchesi S, Skiadopoulos MH, Boivin G, et al. Genetic diversity between human metapneumovirus subgroups. Virology. 2003:315:1-9.

200. Boivin G, Mackay I, Sloots TP, et al. Global genetic diversity of human metapneumovirus fusion gene. Emerg Infect Dis. 2004:10:1154-7.

201. Mackay IM, Bialasiewicz S, Waliuzzaman Z, et al. Use of the P gene to genotype human metapneumovirus identifies 4 viral subtypes. J Infect Dis. 2004;190:1913-8.

202. van den Hoogen BG, Herfst S, Sprong L, et al. Antigenic and genetic variability of human metapneumoviruses. Emerg Infect Dis. 2004;10:658-66.

203. Yang CF, Wang CK, Tollefson SJ, et al. Genetic diversity and evolution of human metapneumovirus fusion protein over twenty years. Virol J. 2009;6:138.

204. Huck B, Scharf G, Neumann-Haefelin D, Puppe W, Weigl J, Falcone V. Novel human metapneumovirus sublineage. Emerg Infect Dis. 2006;12:147-50.

205. Tang RS, Schickli JH, MacPhail M, et al. Effects of human metapneumovirus and respiratory syncytial virus antigen insertion in two 3' proximal genome positions of bovine/human parainfluenza virus type 3 on virus replication and immunogenicity. J Virol. 2003;77:10819-28.

206. Skiadopoulos MH, Biacchesi S, Buchholz UJ, et al. Individual contributions of the human metapneumovirus F, G, and SH surface 
glycoproteins to the induction of neutralizing antibodies and protective immunity. Virology. 2006;345:492-501.

207. Cseke G, Wright DW, Tollefson SJ, Johnson JE, Crowe Jr JE, Williams JV. Human metapneumovirus fusion protein vaccines that are immunogenic and protective in cotton rats. J Virol. 2007;81:698-707.

208. Herfst S, de Graaf M, Schrauwen EJ, et al. Immunization of Syrian golden hamsters with $\mathrm{F}$ subunit vaccine of human metapneumovirus induces protection against challenge with homologous or heterologous strains. J Gen Virol. 2007;88:2702-9.

209. Mok H, Tollefson SJ, Podsiad AB, et al. An alphavirus repliconbased human metapneumovirus vaccine is immunogenic and protective in mice and cotton rats. J Virol. 2008;82:11410-8.

210. Ulbrandt ND, Ji H, Patel NK, et al. Isolation and characterization of monoclonal antibodies which neutralize human metapneumovirus in vitro and in vivo. J Virol. 2006;80:7799-806.

211. Williams JV, Chen Z, Cseke G, et al. A recombinant human monoclonal antibody to human metapneumovirus fusion protein that neutralizes virus in vitro and is effective therapeutically in vivo. J Virol. 2007;81:8315-24.

212. Hamelin ME, Couture C, Sackett M, et al. The prophylactic administration of a monoclonal antibody against human metapneumovirus attenuates viral disease and airways hyperresponsiveness in mice. Antivir Ther. 2008;13:39-46.

213. Hamelin ME, Gagnon C, Prince GA, et al. Prophylactic and therapeutic benefits of a monoclonal antibody against the fusion protein of human metapneumovirus in a mouse model. Antiviral Res. 2010;88:31-7.

214. Ryder AB, Tollefson SJ, Podsiad AB, Johnson JE, Williams JV. Soluble recombinant human metapneumovirus $\mathrm{G}$ protein is immunogenic but not protective. Vaccine. 2010;28:4145-52.

215. Bastien N, Liu L, Ward D, Taylor T, Li Y. Genetic variability of the $\mathrm{G}$ glycoprotein gene of human metapneumovirus. J Clin Microbiol. 2004;42:3532-7.

216. Peret TC, Abed Y, Anderson LJ, Erdman DD, Boivin G. Sequence polymorphism of the predicted human metapneumovirus G glycoprotein. J Gen Virol. 2004;85:679-86.

217. Galiano M, Trento A, Ver L, Carballal G, Videla C. Genetic heterogeneity of $\mathrm{G}$ and $\mathrm{F}$ protein genes from Argentinean human metapneumovirus strains. J Med Virol. 2006;78:631-7.

218. Yang CF, Wang CK, Tollefson SJ, et al. Human metapneumovirus $\mathrm{G}$ protein is highly conserved within but not between genetic lineages. Arch Virol. 2013;158:1245-52.

219. Skiadopoulos MH, Biacchesi S, Buchholz UJ, et al. The two major human metapneumovirus genetic lineages are highly related antigenically, and the fusion $(\mathrm{F})$ protein is a major contributor to this antigenic relatedness. J Virol. 2004;78:6927-37.

220. van den Hoogen BG, Herfst S, de Graaf M, et al. Experimental infection of macaques with human metapneumovirus induces transient protective immunity. J Gen Virol. 2007;88:1251-9.

221. Herfst S, Schrauwen EJ, de Graaf M, et al. Immunogenicity and efficacy of two candidate human metapneumovirus vaccines in cynomolgus macaques. Vaccine. 2008;26:4224-30.

222. Huang CG, Tsao KC, Lin TY, et al. Estimates of individuals exposed to human metapneumovirus in a community-based Taiwanese population in 1999. Arch Virol. 2010;155:343-50.

223. Leung J, Esper F, Weibel C, Kahn JS. Seroepidemiology of human metapneumovirus (hMPV) on the basis of a novel enzyme-linked immunosorbent assay utilizing hMPV fusion protein expressed in recombinant vesicular stomatitis virus. J Clin Microbiol. 2005;43:1213-9.

224. Liu L, Bastien N, Sidaway F, Chan E, Li Y. Seroprevalence of human metapneumovirus (hMPV) in the Canadian province of Saskatchewan analyzed by a recombinant nucleocapsid proteinbased enzyme-linked immunosorbent assay. J Med Virol. 2007; 79:308-13.
225. Ljubin Sternak S, Vilibic Cavlek T, Falsey AR, Walsh EE, Mlinaric Galinovic G. Serosurvey of human metapneumovirus infection in Croatia. Croat Med J. 2006;47:878-81.

226. Lu G, Gonzalez R, Guo L, et al. Large-scale seroprevalence analysis of human metapneumovirus and human respiratory syncytial virus infections in Beijing, China. Virol J. 2011;8:62.

227. Lusebrink J, Wiese C, Thiel A, et al. High seroprevalence of neutralizing capacity against human metapneumovirus in all age groups studied in Bonn, Germany. Clin Vaccine Immunol. 2010;17:481-4.

228. Matsuzaki Y, Itagaki T, Abiko C, Aoki Y, Suto A, Mizuta K. Clinical impact of human metapneumovirus genotypes and genotype-specific seroprevalence in Yamagata, Japan. J Med Virol. 2008;80:1084-9.

229. Mirazo S, Ruchansky D, Blanc A, Arbiza J. Serologic evidence of human metapneumovirus circulation in Uruguay. Mem Inst Oswaldo Cruz. 2005; 100:715-8.

230. Pavlin JA, Hickey AC, Ulbrandt N, et al. Human metapneumovirus reinfection among children in Thailand determined by ELISA using purified soluble fusion protein. J Infect Dis. 2008;198: $836-42$.

231. Wolf DG, Zakay-Rones Z, Fadeela A, Greenberg D, Dagan R. High seroprevalence of human metapneumovirus among young children in Israel. J Infect Dis. 2003;188:1865-7.

232. Banerjee S, Sullender WM, Ahuja RK, Broor S. Seroepidemiological study of human metapneumovirus in New Delhi, India. Indian J Med Microbiol. 2011;29:363-7.

233. Ebihara T, Endo R, Kikuta H, Ishiguro N, Ishiko H, Kobayashi K. Comparison of the seroprevalence of human metapneumovirus and human respiratory syncytial virus. $\mathbf{J}$ Med Virol. 2004;72:304-6.

234. Hamelin ME, Boivin G. Development and validation of an enzyme-linked immunosorbent assay for human metapneumovirus serology based on a recombinant viral protein. Clin Diagn Lab Immunol. 2005;12:249-53.

235. Abdullah Brooks W, Erdman D, Terebuh P, et al. Human metapneumovirus infection among children, Bangladesh. Emerg Infect Dis. 2007;13:1611-3.

236. Takahashi T, Nomura K, Honda $\mathrm{H}$, et al. Association between seroprevalence of human metapneumovirus and $\mathrm{C}$-reactive protein level and apolipoprotein E-epsilon4 allele in elderly inpatients in Japan. J Am Geriatr Soc. 2008;56:1758-60.

237. Okamoto M, Sugawara K, Takashita E, et al. Development and evaluation of a whole virus-based enzyme-linked immunosorbent assay for the detection of human metapneumovirus antibodies in human sera. J Virol Methods. 2010;164:24-9.

238. Williams JV, Edwards KM, Weinberg GA, et al. Population-based incidence of human metapneumovirus infection among hospitalized children. J Infect Dis. 2010;201:1890-8.

239. Ebihara T, Endo R, Kikuta H, et al. Human metapneumovirus infection in Japanese children. J Clin Microbiol. 2004;42: 126-32.

240. Choi EH, Lee HJ, Kim SJ, et al. The association of newly identified respiratory viruses with lower respiratory tract infections in Korean children, 2000-2005. Clin Infect Dis. 2006;43:585-92.

241. Sloots TP, Mackay IM, Bialasiewicz S, et al. Human metapneumovirus, Australia, 2001-2004. Emerg Infect Dis. 2006;12: 1263-6.

242. Madhi SA, Ludewick H, Kuwanda L, van Niekerk N, Cutland C, Klugman KP. Seasonality, incidence, and repeat human metapneumovirus lower respiratory tract infections in an area with a high prevalence of human immunodeficiency virus type-1 infection. Pediatr Infect Dis J. 2007;26:693-9.

243. Peiris JS, Tang WH, Chan KH, et al. Children with respiratory disease associated with metapneumovirus in Hong Kong. Emerg Infect Dis. 2003;9:628-33. 
244. Chen X, Zhang ZY, Zhao Y, Liu EM, Zhao XD. Acute lower respiratory tract infections by human metapneumovirus in children in Southwest China: a 2-year study. Pediatr Pulmonol. 2010;45:824-31.

245. Edwards KM, Zhu Y, Griffin MR, et al. Burden of human metapneumovirus infection in young children. $\mathrm{N}$ Engl $\mathrm{J}$ Med. 2013;368:633-43.

246. Falsey AR, Erdman D, Anderson LJ, Walsh EE. Human metapneumovirus infections in young and elderly adults. J Infect Dis. 2003;187:785-90.

247. Walsh EE, Peterson DR, Falsey AR. Human metapneumovirus infections in adults: another piece of the puzzle. Arch Intern Med. 2008;168:2489-96.

248. Widmer K, Zhu Y, Williams JV, Griffin MR, Edwards KM, Talbot HK. Rates of hospitalizations for respiratory syncytial virus, human metapneumovirus, and influenza virus in older adults. J Infect Dis. 2012;206:56-62.

249. Johnstone J, Majumdar SR, Fox JD, Marrie TJ. Human metapneumovirus pneumonia in adults: results of a prospective study. Clin Infect Dis. 2008;46:571-4.

250. Vanspauwen MJ, van Mook WN, Bruggeman CA, Bergmans DC, Linssen CF. Human metapneumovirus in bronchoalveolar lavage fluid of critically ill patients with suspected pneumonia. Intensive Care Med. 2012;38:728-9.

251. O'Gorman C, McHenry E, Coyle PV. Human metapneumovirus in adults: a short case series. Eur J Clin Microbiol Infect Dis. 2006;25:190-2.

252. Jartti T, Lehtinen P, Vuorinen T, et al. Respiratory picornaviruses and respiratory syncytial virus as causative agents of acute expiratory wheezing in children. Emerg Infect Dis. 2004;10: 1095-101.

253. Rawlinson WD, Waliuzzaman Z, Carter IW, Belessis YC, Gilbert KM, Morton JR. Asthma exacerbations in children associated with rhinovirus but not human metapneumovirus infection. J Infect Dis. 2003;187:1314-8.

254. Khetsuriani N, Kazerouni NN, Erdman DD, et al. Prevalence of viral respiratory tract infections in children with asthma. J Allergy Clin Immunol. 2007;119:314-21.

255. Jartti T, van den Hoogen B, Garofalo RP, Osterhaus AD, Ruuskanen O. Metapneumovirus and acute wheezing in children. Lancet. 2002;360:1393-4.

256. Williams JV, Crowe Jr JE, Enriquez R, et al. Human metapneumovirus infection plays an etiologic role in acute asthma exacerbations requiring hospitalization in adults. J Infect Dis. 2005;192: 1149-53.

257. Broughton S, Sylvester KP, Fox G, et al. Lung function in prematurely born infants after viral lower respiratory tract infections. Pediatr Infect Dis J. 2007;26:1019-24.

258. Garcia-Garcia ML, Calvo C, Casas I, et al. Human metapneumovirus bronchiolitis in infancy is an important risk factor for asthma at age 5. Pediatr Pulmonol. 2007;42:458-64.

259. Klein MI, Coviello S, Bauer G, et al. The impact of infection with human metapneumovirus and other respiratory viruses in young infants and children at high risk for severe pulmonary disease. J Infect Dis. 2006;193:1544-51.

260. Varman M, Truemper EJ, Chatterjee A. Severe human metapneumovirus pneumonia in a child with chronic illness. Clin Pediatr. 2010;49:1075-7.

261. Papenburg J, Hamelin ME, Ouhoummane N, et al. Comparison of risk factors for human metapneumovirus and respiratory syncytial virus disease severity in young children. J Infect Dis. 2012;206:178-89.

262. Morrow BM, Hatherill M, Smuts HE, Yeats J, Pitcher R, Argent AC. Clinical course of hospitalised children infected with human metapneumovirus and respiratory syncytial virus. J Paediatr Child Health. 2006;42:174-8.
263. Zhang SX, Tellier R, Zafar R, Cheung R, Adachi D, Richardson SE. Comparison of human metapneumovirus infection with respiratory syncytial virus infection in children. Pediatr Infect Dis J. 2009;28:1022-4.

264. Esper F, Martinello RA, Boucher D, et al. A 1-year experience with human metapneumovirus in children aged $<5$ years. J Infect Dis. 2004;189:1388-96.

265. Vicente D, Montes M, Cilla G, Perez-Trallero E. Human metapneumovirus and chronic obstructive pulmonary disease. Emerg Infect Dis. 2004;10:1338-9.

266. Hamelin ME, Cote S, Laforge J, et al. Human metapneumovirus infection in adults with community-acquired pneumonia and exacerbation of chronic obstructive pulmonary disease. Clin Infect Dis. 2005;41:498-502.

267. Martinello RA, Esper F, Weibel C, Ferguson D, Landry ML, Kahn JS. Human metapneumovirus and exacerbations of chronic obstructive pulmonary disease. J Infect. 2006;53:248-54.

268. Pelletier G, Dery P, Abed Y, Boivin G. Respiratory tract reinfections by the new human Metapneumovirus in an immunocompromised child. Emerg Infect Dis. 2002;8:976-8.

269. Madhi SA, Ludewick H, Abed Y, Klugman KP, Boivin G. Human metapneumovirus-associated lower respiratory tract infections among hospitalized human immunodeficiency virus type 1 (HIV1)-infected and HIV-1-uninfected African infants. Clin Infect Dis. 2003;37:1705-10.

270. Englund JA, Boeckh M, Kuypers J, et al. Brief communication: fatal human metapneumovirus infection in stem-cell transplant recipients. Ann Intern Med. 2006;144:344-9.

271. Muller A, Kupfer B, Vehreschild J, et al. Fatal pneumonia associated with human metapneumovirus (HMPV) in a patient with myeloid leukemia and adenocarcinoma in the lung. Eur $\mathbf{J}$ Med Res. 2007;12:183-4.

272. Abed Y, Boivin G. Human metapneumovirus infection in immunocompromised child. Emerg Infect Dis. 2008; 14:854-6.

273. Evashuk KM, Forgie SE, Gilmour S, Huynh H, Lee BE, Robinson JL. Respiratory failure associated with human metapneumovirus infection in an infant posthepatic transplant. Am J Transplant. 2008;8:1567-9.

274. Debur MC, Vidal LR, Stroparo E, et al. Human metapneumovirus infection in hematopoietic stem cell transplant recipients. Transpl Infect Dis. 2010;12:173-9.

275. Shahda S, Carlos WG, Kiel PJ, Khan BA, Hage CA. The human metapneumovirus: a case series and review of the literature. Transpl Infect Dis. 2011;13:324-8.

276. Williams JV, Martino R, Rabella N, et al. A prospective study comparing human metapneumovirus with other respiratory viruses in adults with hematologic malignancies and respiratory tract infections. J Infect Dis. 2005;192:1061-5.

277. Tu CC, Chen LK, Lee YS, et al. An outbreak of human metapneumovirus infection in hospitalized psychiatric adult patients in Taiwan. Scand J Infect Dis. 2009;41:363-7.

278. Boivin G, De Serres G, Hamelin ME, et al. An outbreak of severe respiratory tract infection due to human metapneumovirus in a long-term care facility. Clin Infect Dis. 2007;44:1152-8.

279. Kim S, Sung H, Im HJ, Hong SJ, Kim MN. Molecular epidemiological investigation of a nosocomial outbreak of human metapneumovirus infection in a pediatric hemato-oncology patient population. J Clin Microbiol. 2009;47:1221-4.

280. Williams JV, Wang CK, Yang CF, et al. The role of human metapneumovirus in upper respiratory tract infections in children: a 20-year experience. J Infect Dis. 2006;193:387-95.

281. Esper F, Boucher D, Weibel C, Martinello RA, Kahn JS. Human metapneumovirus infection in the United States: clinical manifestations associated with a newly emerging respiratory infection in children. Pediatrics. 2003;111:1407-10. 
282. Ji W, Wang Y, Chen Z, Shao X, Ji Z, Xu J. Human metapneumovirus in children with acute respiratory tract infections in Suzhou, China 2005-2006. Scand J Infect Dis. 2009;41: 735-44.

283. Nokso-Koivisto J, Pyles RB, Miller AL, Patel JA, Loeffelholz M, Chonmaitree T. Viral load and acute otitis media development after human metapneumovirus upper respiratory tract infection. Pediatr Infect Dis J. 2012;31:763-6.

284. Schildgen O, Geikowski T, Glatzel T, Schuster J, Simon A. Frequency of human metapneumovirus in the upper respiratory tract of children with symptoms of an acute otitis media. Eur J Pediatr. 2005; 164:400-1.

285. Suzuki A, Watanabe O, Okamoto M, et al. Detection of human metapneumovirus from children with acute otitis media. Pediatr Infect Dis J. 2005;24:655-7.

286. Schildgen O, Glatzel T, Geikowski T, et al. Human metapneumovirus RNA in encephalitis patient. Emerg Infect Dis. 2005; 11:467-70.

287. Glaser CA, Honarmand S, Anderson LJ, et al. Beyond viruses: clinical profiles and etiologies associated with encephalitis. Clin Infect Dis. 2006;43:1565-77.

288. Hata M, Ito M, Kiyosawa S, et al. A fatal case of encephalopathy possibly associated with human metapneumovirus infection. Jpn J Infect Dis. 2007;60:328-9.

289. Kaida A, Iritani N, Kubo H, Shiomi M, Kohdera U, Murakami T. Seasonal distribution and phylogenetic analysis of human metapneumovirus among children in Osaka City, Japan. J Clin Virol. 2006;35:394-9.

290. Arnold JC, Singh KK, Milder E, et al. Human metapneumovirus associated with central nervous system infection in children. Pediatr Infect Dis J. 2009;28:1057-60.

291. Sanchez Fernandez I, Rebollo Polo M, Munoz-Almagro C, et al. Human metapneumovirus in the cerebrospinal fluid of a patient with acute encephalitis. Arch Neurol. 2012;69:649-52.

292. Regev L, Hindiyeh M, Shulman LM, et al. Characterization of human metapneumovirus infections in Israel. J Clin Microbiol. 2006;44:1484-9.

293. Kim YK, Lee HJ. Human metapneumovirus-associated lower respiratory tract infections in Korean infants and young children. Pediatr Infect Dis J. 2005;24:1111-2.

294. Lambert SB, Allen KM, Druce JD, et al. Community epidemiology of human metapneumovirus, human coronavirus NL63, and other respiratory viruses in healthy preschool-aged children using parent-collected specimens. Pediatrics. 2007;120:e929-37.

295. Galiano M, Videla C, Puch SS, Martinez A, Echavarria M, Carballal G. Evidence of human metapneumovirus in children in Argentina. J Med Virol. 2004;72:299-303.

296. Ali SA, Williams JV, Chen Q, et al. Human metapneumovirus in hospitalized children in Amman, Jordan. J Med Virol. 2010;82:1012-6.

297. Oliveira DB, Durigon EL, Carvalho AC, et al. Epidemiology and genetic variability of human metapneumovirus during a 4-yearlong study in Southeastern Brazil. J Med Virol. 2009;81:915-21.

298. Aberle SW, Aberle JH, Sandhofer MJ, Pracher E, Popow-Kraupp T. Biennial spring activity of human metapneumovirus in Austria. Pediatr Infect Dis J. 2008;27:1065-8.

299. Heininger U, Kruker AT, Bonhoeffer J, Schaad UB. Human metapneumovirus infections-biannual epidemics and clinical findings in children in the region of Basel, Switzerland. Eur J Pediatr. 2009;168:1455-60.

300. Mullins JA, Erdman DD, Weinberg GA, et al. Human metapneumovirus infection among children hospitalized with acute respiratory illness. Emerg Infect Dis. 2004;10:700-5.

301. Louie JK, Schnurr DP, Pan CY, et al. A summer outbreak of human metapneumovirus infection in a long-term-care facility. J Infect Dis. 2007;196:705-8.
302. Semple MG, Cowell A, Dove W, et al. Dual infection of infants by human metapneumovirus and human respiratory syncytial virus is strongly associated with severe bronchiolitis. J Infect Dis. 2005;191:382-6.

303. van Woensel JB, Bos AP, Lutter R, Rossen JW, Schuurman R. Absence of human metapneumovirus co-infection in cases of severe respiratory syncytial virus infection. Pediatr Pulmonol. 2006;41:872-4.

304. Lazar I, Weibel C, Dziura J, Ferguson D, Landry ML, Kahn JS. Human metapneumovirus and severity of respiratory syncytial virus disease. Emerg Infect Dis. 2004;10:1318-20.

305. Singleton RJ, Bulkow LR, Miernyk K, et al. Viral respiratory infections in hospitalized and community control children in Alaska. J Med Virol. 2010;82:1282-90.

306. Kaida A, Kubo H, Goto K, Shiomi M, Kohdera U, Iritani N. Co-infection of human metapneumovirus with adenovirus or respiratory syncytial virus among children in Japan. Microbiol Immunol. 2007;51:679-83.

307. Lee N, Chan PK, Yu IT, et al. Co-circulation of human metapneumovirus and SARS-associated coronavirus during a major nosocomial SARS outbreak in Hong Kong. J Clin Virol. 2007;40:333-7.

308. Gerna G, Campanini G, Rovida F, et al. Changing circulation rate of human metapneumovirus strains and types among hospitalized pediatric patients during three consecutive winter-spring seasons. Arch Virol. 2005;150:2365-75.

309. Vicente D, Montes M, Cilla G, Perez-Yarza EG, Perez-Trallero E. Differences in clinical severity between genotype A and genotype B human metapneumovirus infection in children. Clin Infect Dis. 2006;42:e111-3.

310. Pitoiset C, Darniot M, Huet F, Aho SL, Pothier P, Manoha C. Human metapneumovirus genotypes and severity of disease in young children $(n=100)$ during a 7-year study in Dijon hospital, France. J Med Virol. 2010;82:1782-9.

311. Agapov E, Sumino KC, Gaudreault-Keener M, Storch GA, Holtzman MJ. Genetic variability of human metapneumovirus infection: evidence of a shift in viral genotype without a change in illness. J Infect Dis. 2006;193:396-403.

312. Kuiken T, van den Hoogen BG, van Riel DA, et al. Experimental human metapneumovirus infection of cynomolgus macaques (Macaca fascicularis) results in virus replication in ciliated epithelial cells and pneumocytes with associated lesions throughout the respiratory tract. Am J Pathol. 2004;164: 1893-900.

313. Kolli D, Bataki EL, Spetch L, et al. T lymphocytes contribute to antiviral immunity and pathogenesis in experimental human metapneumovirus infection. J Virol. 2008;82:8560-9.

314. Williams JV, Tollefson SJ, Johnson JE, Crowe Jr JE. The cotton rat (Sigmodon hispidus) is a permissive small animal model of human metapneumovirus infection, pathogenesis, and protective immunity. J Virol. 2005;79:10944-51.

315. Sumino KC, Agapov E, Pierce RA, et al. Detection of severe human metapneumovirus infection by real-time polymerase chain reaction and histopathological assessment. $J$ Infect Dis. 2005;192:1052-60.

316. Vargas SO, Kozakewich HP, Perez-Atayde AR, McAdam AJ. Pathology of human metapneumovirus infection: insights into the pathogenesis of a newly identified respiratory virus. Pediatr Dev Pathol. 2004;7:478-86.

317. Bao X, Liu T, Shan Y, Li K, Garofalo RP, Casola A. Human metapneumovirus glycoprotein $\mathrm{G}$ inhibits innate immune responses. PLoS Pathog. 2008;4:e1000077.

318. Dinwiddie DL, Harrod KS. Human metapneumovirus inhibits IFN-alpha signaling through inhibition of STAT1 phosphorylation. Am J Respir Cell Mol Biol. 2008;38: 661-70. 
319. Erickson JJ, Gilchuk P, Hastings AK, et al. Viral acute lower respiratory infections impair CD8+ T cells through PD-1. J Clin Invest. 2012;122:2967-82.

320. Peret TC, Boivin G, Li Y, et al. Characterization of human metapneumoviruses isolated from patients in North America. J Infect Dis. 2002;185:1660-3.

321. Falsey AR, Hennessey PA, Formica MA, Criddle MM, Biear JM, Walsh EE. Humoral immunity to human metapneumovirus infection in adults. Vaccine. 2010;28:1477-80.

322. Boivin G, De Serres G, Cote S, et al. Human metapneumovirus infections in hospitalized children. Emerg Infect Dis. 2003;9:634-40.

323. Zhang HY, Li ZM, Zhang GL, Diao TT, Cao CX, Sun HQ. Respiratory viruses in hospitalized children with acute lower respiratory tract infections in Harbin, China. Jpn J Infect Dis. 2009;62:458-60.

324. van den Hoogen BG, van Doornum GJ, Fockens JC, et al. Prevalence and clinical symptoms of human metapneumovirus infection in hospitalized patients. J Infect Dis. 2003;188: 1571-7.

325. Osterhaus A, Fouchier R. Human metapneumovirus in the community. Lancet. 2003;361:890-1.

326. Banerjee S, Sullender WM, Choudekar A, et al. Detection and genetic diversity of human metapneumovirus in hospitalized children with acute respiratory infections in India. J Med Virol. 2011;83:1799-810.

327. Kunz AN, Englund JA, Kuypers J, Maranich A, Fairchok MP. Detection of multiple respiratory viruses by real-time polymerase chain reaction in infants attending an outpatient clinic. Eur J Clin Microbiol Infect Dis. 2008;27:1245-8.

328. Reina J, Ferres F, Alcoceba E, Mena A, de Gopegui ER, Figuerola J. Comparison of different cell lines and incubation times in the isolation by the shell vial culture of human metapneumovirus from pediatric respiratory samples. J Clin Virol. 2007; 40:46-9.

329. Ebihara T, Endo R, Ma X, Ishiguro N, Kikuta H. Detection of human metapneumovirus antigens in nasopharyngeal secretions by an immunofluorescent-antibody test. J Clin Microbiol. 2005;43:1138-41.

330. Percivalle E, Sarasini A, Visai L, Revello MG, Gerna G. Rapid detection of human metapneumovirus strains in nasopharyngeal aspirates and shell vial cultures by monoclonal antibodies. J Clin Microbiol. 2005;43:3443-6.

331. Boivin G, Abed Y, Pelletier G, et al. Virological features and clinical manifestations associated with human metapneumovirus: a new paramyxovirus responsible for acute respiratory-tract infections in all age groups. J Infect Dis. 2002;186: $1330-4$.
332. Cote S, Abed Y, Boivin G. Comparative evaluation of real-time PCR assays for detection of the human metapneumovirus. J Clin Microbiol. 2003;41:3631-5.

333. Hamelin ME, Prince GA, Boivin G. Effect of ribavirin and glucocorticoid treatment in a mouse model of human metapneumovirus infection. Antimicrob Agents Chemother. 2006;50:774-7.

334. Wyde PR, Chetty SN, Jewell AM, Boivin G, Piedra PA. Comparison of the inhibition of human metapneumovirus and respiratory syncytial virus by ribavirin and immune serum globulin in vitro. Antiviral Res. 2003;60:51-9.

335. Wyde PR, Moylett EH, Chetty SN, Jewell A, Bowlin TL, Piedra PA. Comparison of the inhibition of human metapneumovirus and respiratory syncytial virus by NMSO3 in tissue culture assays. Antiviral Res. 2004;63:51-9.

336. Kamble RT, Bollard C, Demmler G, LaSala PR, Carrum G. Human metapneumovirus infection in a hematopoietic transplant recipient. Bone Marrow Transplant. 2007;40:699-700.

337. Bonney D, Razali H, Turner A, Will A. Successful treatment of human metapneumovirus pneumonia using combination therapy with intravenous ribavirin and immune globulin. Br J Haematol. 2009;145:667-9.

338. Shachor-Meyouhas Y, Ben-Barak A, Kassis I. Treatment with oral ribavirin and IVIG of severe human metapneumovirus pneumonia (HMPV) in immune compromised child. Pediatr Blood Cancer. 2011;57:350-1.

339. Tang RS, Mahmood K, Macphail M, et al. A host-range restricted parainfluenza virus type 3 (PIV3) expressing the human metapneumovirus (hMPV) fusion protein elicits protective immunity in African green monkeys. Vaccine. 2005;23:1657-67.

340. Herfst S, de Graaf M, Schickli JH, et al. Recovery of human metapneumovirus genetic lineages a and B from cloned cDNA. J Virol. 2004;78:8264-70.

341. Biacchesi S, Pham QN, Skiadopoulos MH, Murphy BR, Collins PL, Buchholz UJ. Infection of nonhuman primates with recombinant human metapneumovirus lacking the $\mathrm{SH}, \mathrm{G}$, or M2-2 protein categorizes each as a nonessential accessory protein and identifies vaccine candidates. J Virol. 2005;79:12608-13.

342. Buchholz UJ, Biacchesi S, Pham QN, et al. Deletion of M2 gene open reading frames 1 and 2 of human metapneumovirus: effects on RNA synthesis, attenuation, and immunogenicity. J Virol. 2005;79:6588-97.

343. Herfst S, de Graaf M, Schrauwen EJ, et al. Generation of temperature-sensitive human metapneumovirus strains that provide protective immunity in hamsters. J Gen Virol. 2008;89:1553-62.

344. Schickli JH, Kaur J, Macphail M, Guzzetta JM, Spaete RR, Tang RS. Deletion of human metapneumovirus M2-2 increases mutation frequency and attenuates growth in hamsters. Virol J. 2008;5:69. 